University of Chicago Law School

Chicago Unbound

Journal Articles

Faculty Scholarship

1959

\title{
The Interstate Commerce Commission as Lawmaker: The Development of Standards for Modification of Railroad Securities
}

Walter J. Blum

Follow this and additional works at: https://chicagounbound.uchicago.edu/journal_articles

Part of the Law Commons

\section{Recommended Citation}

Walter J. Blum, "The Interstate Commerce Commission as Lawmaker: The Development of Standards for Modification of Railroad Securities," 27 University of Chicago Law Review 603 (1959).

This Article is brought to you for free and open access by the Faculty Scholarship at Chicago Unbound. It has been accepted for inclusion in Journal Articles by an authorized administrator of Chicago Unbound. For more information, please contact unbound@law.uchicago.edu. 


\title{
THE
}

\section{UNIVERSITY OF CHICAGO LAW REVIEW \\ VOLUME 27 \\ SUMMER 1960 \\ NUMBER 4}

\section{THE INTERSTATE COMMERCE COMMISSION AS LAWMAKER: THE DEVELOPMENT OF STANDARDS FOR MODIFICATION OF RAILROAD SECURITIES}

\author{
WALTER J. BLuM*
}

I

$\mathrm{R}$

ECENT ATTACKS on the independent regulatory commissions of the federal government have again focused attention on how well these agencies succeed in developing doctrine which gives content to more general legislative standards. Since their inception it has been assumed generally that such subordinate principles would emerge from the expert skill and knowledge of the commissions, whether they operated by laying down rules purporting to have broad application or by rendering opinions on a case to case basis. This assumption is central to the place of administrative agencies in our scheme of governmental control over economic activities. It encourages us to regard them as more than mere umpires or juries, and as being entitled to a dignity approaching that of legislatures and courts. They are, in a word, to be viewed as lawmakers, junior grade. Under the circumstances it is important that we be alerted whenever the central assumption is not consistent with the facts. To the degree that a commission is unable to develop doctrine, and thus fails to discipline itself and give guidance to those subject to its power, we might be moved to conclude that control by government should take another form, or that the composition or role of the agency should be drastically altered.

It is against this backdrop that one aspect of opinions rendered by the Interstate Commerce Commission under section $20 \mathrm{~b}$ of the Interstate Commerce Act, ${ }^{1}$ sometimes referred to as the railroad modification law, will be reviewed. The concern will be with the agency's handling of the statutory requirement that, to be approved by the Commission, a proposed securities alteration or

* Professor of Law, University of Chicago.

171 Stat. 369 (1957), 49 U.S.C. \& 20b (1958). 
modification "will be in the best interests ... of each class of its stockholders, and of the holders of each class of its obligations affected by such modification or alteration...."2 That this looks at a segment of the ICC's activities is both true and intended. For the purpose of this treatment it seems more fruitful to explore a small area in detail, even at the risk of not covering enough of the Commission's operations to offer compelling generalizations. This risk is minimized to a considerable extent in the case of the area chosen for study. The modification of railroad securities involves financial matters with which the Commission has had extensive experience, and the modification function, though comparatively minor in itself, is directly related to the agency's main role of assuring a sound and economical transportation system. We therefore can assume that the Commission takes its duties in modification proceedings seriously and that shortcomings in its reports are not attributable to inexperience in dealing with the financial structures of railroads. The standard selected, moreover, has the additional advantage of being divorced from that vaguest of vague notions-the public interest; for to be fair to the central assumption, we ought at least to start with a legislative prescription which offers more hope of meaningful implementation than some version of the common good.

For this inquiry a brief summary of section 20b will suffice. Enacted in 1948 as an aid to the national transportation policy, the section establishes a voluntary extra-judicial procedure by which a railroad can modify its securities through obtaining the approval of the ICC and the consent of at least 75 percent of "the aggregate principal amount or number of shares outstanding of each class of securities affected"3 by the proposed modification. Among the goals stated in the preamble to be in aid of the transportation policy are "to assure, insofar as possible, continuity of sound financial condition of [interstate railroads]; to enhance the marketability of railroad securities impaired by large and continuing accumulations of interest on income bonds and dividends on preferred stock; and to enable said common carriers, insofar as possible, to avoid prospective financial difficulties, inability to meet debts as they mature, and insolvency." A proposal for modification of its securities can be advanced only by the railroad company. The Commission is to authorize submission of a proposed modification to all affected classes of security-holders if, in the words of the statute, it "shall find that, subject to such terms and conditions and with such amendments as it shall determine to be just and reasonable, the proposed alteration or modification-(a) is within the scope [of the act], (b) will be in the public interest, (c) will be in the best interests of the carrier, of each class of its

271 Stat. 369 (1957), 49 U.S.C. $\$ 20 \mathrm{~b}(2)$ (c) (1958).

371 Stat. 369 (1957), 49 U.S.C. $\$ 20(2)$ (1958). In any case where $75 \%$ of the principal amount or number of shares outstanding "is held by fewer than twenty-five holders," the required level of acceptance is to be "such larger percentage, if any, as the Commission may determine to be just and reasonable and in the public interest."

463 Stat. 107 (1949), 49 U.S.C. \& 20b, Preamble (1958). 
stockholders, and of the holders of each class of its obligations affected; and (d) will not be adverse to the interests of any creditor of the carrier not affected by such modification...." While our concern will be with the best interests of stockholders and affected classes of creditors, an occasional reference to the other requirements will be in order.

It is well to observe now that the draftsmanship of the act invites some confusion about the legislative standards. A quick reading might give the impression that the Commission must find that a plan of modification is "just and reasonable" before authorizing its submission. A closer inspection reveals that only amendments made by the Commission (and perhaps also terms and conditions imposed by it) need satisfy this test. Such a literal construction of the language, however, would lead to strange results: a plan sanctioned without alteration by the Commission would not have to be just and reasonable, whereas any change introduced in a plan by it would be held to that standard. This awkwardness can be avoided by inferring that, when confronted with a plan which is unacceptable in some respects but which otherwise satisfies the statutory requirements, the ICC may make such amendments as will correct the inadequacies and conform the whole proposal to the governing standard. ${ }^{6}$ Whether or not the suggested interpretation is adopted, the statutory language would seem to make it difficult for the Commission to pass on the "best interests" of stockholders and creditors without making reference to the "just and reasonable" clause in some cases. Our inquiry thus must be widened to include both statutory phrases. In slightly more general terms it can be restated as follows: To what extent has the ICC developed principles for determining what constitutes an acceptable exchange of rights for shareholders or creditors in a modification of railroad securities? What, in brief, is the appropriate measure for determining whether an exchange of old for new rights shortchanges or overcompensates some participants?

A much condensed history of the railroad modification law and its antecedents will serve to put this question in proper perspective. ${ }^{7}$ The earliest railroad and other corporate reorganizations in the United States were worked out by

571 Stat. 369 (1957), 49 U.S.C. $\$ 20 \mathrm{~b}(2)$ (1958).

" "Some hold that the statute does not give the Commission the duty of determining the fairness of the plan but, on the contrary, was phrased carefully to avoid such a positive duty. The phrase 'just and reasonable' they assume to refer strictly to the amendments the Commission may make, although such changes are not measured by any standard of fairness it is obliged to enforce." MASSON, NEw SHARES FOR OLD 368 (1958). "It seems wholly illogical however, that the position of the phrase ('with such amendments as it shall determine to be just and reasonable') should carry such weight in an argument as to its meaning. . . . The phrase can be looked on as describing the obvious course expected of a regulatory agency, namely, that if it makes amendments to a proposed plan, they be consistent with the original plan and supportable on the same reasoned basis." Id, at 177.

7 The history is reviewed at length in Hand and Cummings, The Railroad Modificalion Law, 48 CoLtr. L. Rev. 689 (1948). A summary of section $20 \mathrm{~b}$ plans passed upon by theICCprior to 1952 is included, as an appendix, in Wren, Feasibility and Fairness in Section $20 b$ Reorganiza tions, 52 Colus. L. REv. 715, 740-45 (1952). 
making ingenious use of a consent receivership in equity. In theory the receivership was not for the purpose of accomplishing a reorganization but of preserving property values until they could be realized through a judicial sale, and adherence to any accompanying plan of reorganization was regarded as a voluntary act by the individual security holder. Consequently a plan could be subjected to official scrutiny only by dragging it into the proceedings through a side door of questionable status. There thus was little development of doctrine governing the propriety of exchanges in receivership reorganizations. The opinions went little beyond the elementary notion that a plan which was so grossly unfair as to destroy the interests of junior creditors without compensating them, while allowing the old stockholders to participate in the reorganized company, was vulnerable to attack by the junior creditors as a fraudulent transfer of corporate assets. In the early thirties the receivership route to reorganization was replaced by comprehensive statutory procedures under the Bankruptcy Actsection 77 for interstate railroads and section $77 \mathrm{~B}$, later chapter $\mathrm{X}$, for industrial companies. The statutory schemes were designed to make results more uniform, eliminate various uncertainties and abuses, give greater control over the reorganization process to the courts and government administrative agencies (particularly the ICC and the SEC), and bind security holders to a plan even though they voted against it. Because dissenters could be bound, the precise terms of a plan became crucial; and the statutes specifically provided that a plan could be approved and confirmed only if it were fair and equitable. The task of providing content to the phrase "fair and equitable" was left ultimately to the courts, with assistance to be provided by the administrative agencies through their reports and advice.

During the late thirties and the first half of the forties, the contours of the fair and equitable standard took fairly definite shape, although gaps remained. ${ }^{8}$ Composition with creditors was ruled out. Security holders are entitled to full compensation: they must be compensated for the rights they surrender and be made whole before a junior class can participate in the reorganization. In determining priorities among classes of securities, the ordering and measurement of claims is to proceed as though an involuntary liquidation were taking place since bankruptcy reorganization is a substitute for enforcement of rights through liquidation of the enterprise. To provide a meaningful basis for determining when compensation is full, a value must be placed upon the enterprise or its capitalization must be set; and in this process primary consideration is to be given to prospective earnings. But though compensation is to be full and is to be predicated predominantly on foreseeable earnings, there is no requirement that dollar values be placed on what a security holder surrenders and on what he receives in the exchange.

${ }^{8}$ The development is traced in Billyou, Priorily Rights of Security Holders in Bankruplcy Reorganization: New Directions, 67 HaRv. L. REv. 53 (1954). But see Blum, The "New Directions" for Priority Rights in Bankntptcy Reorganizations, 67 HARV. L. REv. 1367 (1954). 
These directives, the courts made clear, were applicable to both railroad and industrial reorganizations. They obviously gave the administrative agencies wide scope to evolve principles for valuing or capitalizing an enterprise in distress. The SEC by and large tended to champion more conservative values, typically reached by estimating the most probable annual earnings and capitalizing these forecasts at rates which best took account of the risks involved. In contrast, the ICC in the main favored using highly optimistic projections of earnings, dividing them into various strata against which specific classes of new securities were authorized. As a result, plans approved by the SEC called for new capital structures with considerably smaller components of water than ICC-sponsored plans. Both agencies, however, accepted and fostered the principles that in bankruptcy reorganizations the claims of security holders are measured by their matured liquidation rights, and holders of senior securities are entitled to be compensated in full before juniors are admitted to participation.9

In the late thirties, before these main guidelines had been spelled out by the courts, a segment of the railroad industry succeeded in getting additional legislation, of short duration, to deal with the situation of carriers whose financial distress was expected to be only temporary. Chapter XV, added to the Bankruptcy Act for one year in 1939, and then again from 1942 to 1945, permitted a road to adjust its capital structure so as to avoid what appeared to be transient financial difficulties by securing approval of a plan from a certain percentage of its security holders, the ICC and the bankruptcy court.10 To approve a plan which would be binding on dissenters, the court was required to find that it was "in the best interests of each class of creditors and stockholders" and that it was "fair and equitable as an adjustment." Partially because of the short life of chapter XV and the small number of proceedings under it, the content of this latter variation of the fair and equitable standard for bankruptcy reorganizations was never given detailed articulation. The prevailing assumption, however, was that it was not intended to depart significantly from the more permanent standard for bankruptcy reorganizations.

These bits of history are close antecedents of the railroad modification law and are directly related to the problem of developing a standard for an acceptable exchange of rights in modifications. Almost from its inception chapter $\mathrm{XV}$ was recognized to be an inadequate vehicle for accomplishing financial readjustments in the railroad industry. Being rooted in the bankruptcy power, it afforded relief solely for railroads which could demonstrate that they were unable to meet their debts "matured or about to mature." Only to the extent that "about to mature" was given a strained meaning could the act be used to accomplish adjustments which anticipated and sought to avoid financial diffi-

\footnotetext{
- These aspects of the doctrine which emerged are considered in Blum, Full Priorily and Full Compensation in Corporate Reorganizations, A Reappraisal, 25 U. CEI. L. REV. 417 (1958).

${ }^{10} \mathrm{Ch}$. XV of Bankruptcy Act of 1898, 56 Stat. 787 (1942).
} 
culties in the more distant future. Further, the "fair and equitable as an adjustment" requirement, which also stemmed from the bankruptcy genesis of the chapter, was viewed as too confining. Since this test was thought to import doctrine associated with bankruptcy reorganizations, conceived of as a substitute for liquidation, it seemed singularly inappropriate for adjustments in situations free of urgent financial distress. To these shortcomings of chapter XV as a model for accomplishing the modification of securities, there was coupled a growing dissatisfaction with section 77 on the part of junior security holders, who saw the full priority doctrine operating to eliminate or substantially reduce their participation in reorganized railroads. ${ }^{11}$ Within this group it was widely hoped that a statutory authorization for voluntary modification of capital structures would provide an escape from the "forfeitures" which occurred under the full priority doctrine, even as tempered by the liberal capitalization policy pursued by the ICC. All of these considerations led to the conclusion that a voluntary modification law, to serve the various functions envisaged, would have to be based on some authorization other than the bankruptcy power and would have to avoid taking over the standard for acceptable exchanges which had developed within its framework.

In using the phrase "best interests" of security-holders (and "just and reasonable" amendments) in section $20 \mathrm{~b}$, it is fairly clear that Congress intended that the ICC not be bound by the bankruptcy reorganization precedents. Nothing more on this subject, however, can be learned with confidence from the congressional history. The ICC apparently was given an almost uncharted course for instilling meaning into the statutory language. In performing this work, the Commission was not to have the assistance or resistance of the courts. Unlike reorganizations under the Bankruptcy Act, in which the courts are charged with finding that a plan is fair and equitable before approving or confirming it, ${ }^{12}$ under section $20 \mathrm{~b}$ the ICC is exclusively responsible for ascertaining whether a plan of modification is in the best interests of the affected classes. The action of the Commission in approving a plan for submission to security holders is subject to court review only to the narrow extent that actions of administrative agencies are in general reviewable. In effect this means that a determination by the Commission that a plan satisfies the best interests test will be disturbed only if its version of the standard is clearly improper, or if the record contains no evidence to substantiate a finding that the test has been met in the particular case.

Two other background items remain to be noted.

The phrase "best interests" of a class is not unique to section 20b (and

11 See dissenting opinion in Insurance Group Comm. v. Denver and Rio Grande Western R.R., 329 U.S. 607 (1947).

1271 Stat. 369 (1957), 49 U.S.C. § 20b (1958); 66 Stat. 433 (1952), 11 U.S.C. $\$ \S 574,621(2)$ (1958). 
Chapter XV of the Bankruptcy Act). Before 1938, a composition in bankruptcy was to be approved only if the judge was satisfied that, among other things, it was "for the best interests of the creditors", ${ }^{13}$ and the same language now expresses a requisite to confirmation of an arrangement with creditors under Chapter XI of the Bankruptcy Act. ${ }^{14}$ The development of the standard in these contexts has not been elaborate. Any intensive inquiry to determine whether a composition is in the best interests of the creditors, after it had been accepted by a majority, would have compelled courts to review the wisdom of all sorts of business considerations, many of a delicate nature. Rather than indulge in this pursuit, for which they are unlikely to be well equipped, most courts adopted a relatively simple interpretation of the statutory requirement. In essence it is that a composition or arrangement is for the best interests of creditors if it is calculated to give them not substantially less than they could expect to receive in liquidation of the debtor through an ordinary bankruptcy proceeding. ${ }^{15} \mathrm{It}$ is obvious that this yardstick could hardly be useful or appropriate in railroad modification situations. Liquidation is not an alternative to a modification, and reliable information concerning liquidation values would be difficult to compile, even for the ICC.

The other background piece is the emergence of a standard of acceptable exchanges in readjustments under the Public Utility Holding Company Act. ${ }^{16}$ This statute, passed in 1935, copied the reorganization sections of the Bankruptcy Act in providing that, to be approved by the SEC and the courts, a plan of adjustment must be "fair and equitable."17 By the time that section 20b became law, the Supreme Court had endorsed the SEC's position that, despite the sameness of the statutory language, liquidation priorities did not control in Holding Company Act readjustments as they did in bankruptcy reorganizations..$^{18}$ Specifically, the Court decided that a preferred stock arrearage need only be accorded priority for its investment value in a continuing business rather than for its claim in an involuntary liquidation. The basis for reaching this result would seem to have a direct bearing on the problem of implementing the "best interests" phraseology of section 20b. In rejecting liquidation priorities as controlling, the Court observed that while bankruptcy reorganizations are a substitute for enforcing rights through liquidation in the case of companies in financial difficulty, readjustments under the Holding Company Act

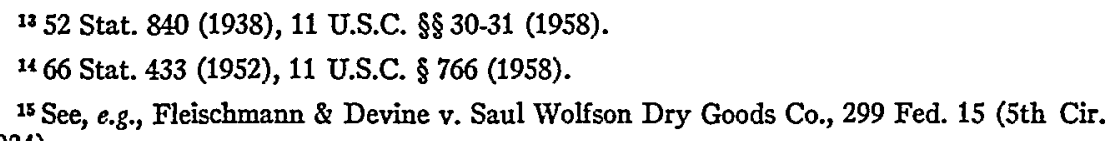
1924).

1649 Stat. 803 (1935), 15 U.S.C. $\$ \S 79 \mathrm{a}-79 \mathrm{k}$ (1958).

1749 Stat. 821 (1935), 15 U.S.C. $879 \mathrm{k}$ (d) (1958).

13 Otis \& Co. v. SEC, 323 U.S. 624 (1945). 
are compelled by notions of public policy relating to the operation of utility holding companies and not by the financial distress of the enterprises. Default rights are therefore not to be regarded as matured.

We are now almost ready to turn to the reports in which the ICC considered the standard of acceptable exchanges under the railroad modification law. They will be reviewed in the order in which they appeared. The survey will be confined largely to those ingredients which might tend to explain why the Commission thought a plan was or was not in the best interests of a class of security holders. Matters concerning procedure, and any judicial review of the agency's opinions, will in the main be treated in the footnotes.

It is worth emphasizing as a last preliminary note that modifications under section $20 \mathrm{~b}$ share a basic feature with proceedings under all the other statutes referred to: The special need for government intervention arises because some of the affected parties are unwilling to concur in the proposed alteration of their rights. Thus official intervention ultimately is designed to coerce non-assenters. To put it another way, if all affected security holders voluntarily agreed to a plan, government action (except perhaps to deal with fraud, misrepresentation, duress and the like), would not be required. ${ }^{19}$ It follows that a standard for acceptable exchanges has the effect of defining the quality of the treatment to which the non-assenters are entitled. Such a standard serves the same function for those security holders who are moved to assent because a government agency or court has put its stamp of approval on the plan..$^{20}$

II

a) Macon, Dublin \& Savannah Railroad (December 9, 1948).2L-The Macon, Dublin \& Savannah was a small road, all of whose stock was owned by Seaboard Air Line, and much of whose business was attributable to the Seaboard, a large railroad, which was said to be in a position to divert this traffic to another carrier. The proposed plan $^{22}$ would have extended for twenty-five years the maturity date of the applicant's only debt securities, 5 per cent first mortgage bonds, which were then already past due, and which were largely held by the public. During the extension the interest rate would remain unchanged, but a sinking fund of the "if earned" variety would be established and dividends on the applicant's stock would be prohibited until at least one-half the outstanding bonds had been retired. The ICC approved the plan, finding it to be in the best

\footnotetext{
19 The ICC, however, has general jurisdiction over the issuance of railroad securities and their terms.

${ }^{20}$ See Blum, The Law and Language of Corporate Reorganization, 17 U. CHr. L. Rev. 565 (1950).

21271 I.C.C. 376 (1948). See also 271 I.C.C. 478 (1949).

${ }_{22}^{2} I d$. at 377 . A substantially identical plan previously had been advanced under section $20 \mathrm{a}$ of the Interstate Commerce Act and had received assents from more than $75 \%$ of the bondholders.
} 
interests of the bondholders without making amendments relevant to our study. ${ }^{23}$

An intervenor had contended that "the plan provides no consideration for the bondholders for the proposed extension of the maturity of the bonds." ${ }^{24}$ To this objection the Commission replied that it ignored the establishment of the sinking fund and the restriction on dividends, but "more importantly," the plan "avoids for the present a possible disturbance of existing traffic relations with the Seaboard, which ... apparently, might result from any plan contemplating a diminution of the Seaboard's proprietary interest in the applicant." ${ }^{25}$ Later in the report the Commission, in dealing with the contention of another intervenor, says that for "reasons ... stated above," in addition to the need to preserve the Seaboard's business, "we do not deem necessary a transfer of any stock to the bondholders." ${ }^{26}$ Apparently the reference is to strengthening the extended bonds through addition of a sinking fund and restricting dividends, but the text is not clear.

This is virtually an exhaustive presentation of the ICC's remarks possibly bearing on the standard to govern exchanges of rights. ${ }^{27}$ The fact is that there is no explicit discussion of what the standard should be and no effort is made to state a test. Several relevant propositions, however, might be inferred from the opinion. The Commission appears to have agreed with the intervenor that, in general, the bondholders were entitled to some consideration for the extension; but this concurrence does not provide us with a guide for ascertaining how much consideration. Moreover, it seems that consideration for an extension might not be called for where the bondholders must look to the continued cooperation of a sole (or dominant) shareholder in order to maintain the earning power of the carrier and hence the value of their securities. The relationship between these conjectural doctrines is open to further speculation. Would it, for example, be appropriate for a plan to provide for an extension of debt at a reduced rate of interest where the controlling stockholder might be able to undermine corporate earnings if the proposal were not effectuated? In more general terms, to what

${ }^{23} \mathrm{Id}$. at $389-90$.

24 $I d$. at 382 .

${ }^{25}$ Ibid.

${ }^{26} \mathrm{Id}$. at 385 . This intervenor had contended that "the proposed extended bonds should be guaranteed by the Seaboard," or in the alternative that "the Seaboard ought to transfer 49 per cent of its holdings of the applicant's stock to the bondholders in order partially to compensate them for applicant's failure to pay the bonds at maturity; or should pay those bondholders who do not wish to extend their bonds. ..." Ibid.

${ }^{27}$ In answering an intervenor's contention that "the plan does not promote the public interest in increased stability of values of railroad securities, with resulting greater confidence therein of investors," the ICC said: "It is clear that where, as here, a defaulted bond is compared with an extended bond resting on the same property, security, and earning power, the extended bond has or should have an increased stability of value, greater confidence of investors, and enhanced marketability." Id. at 381-82. This remark apparently was not directed by the ICC to the standard for acceptable exchanges imposed on security holders. 
extent can a dominant stockholder demand a forfeiture of rights by creditors who are dependent upon continuation of patronage which the shareholder controls?

The report furnishes no clue to the answer, and does not even raise the question. But it gives the distinct impression that the Commission saw nothing wrong in a parent carrier using control over traffic to force creditors of its subsidiary into line in a modification proceeding. Whether or not the threat of Seaboard was more than a bluff, ${ }^{28}$ the Commission never once suggested that the creditors could look to it for protection against this type of imposition, or that the threat itself might be evidence that the plan was not in their best interests. ${ }^{29}$ Instead we are left to conclude that the parent is free to utilize its dual position for its own ends - in this case to arrange an extension of the subsidiary's debt without sharing its equity interest with the bondholders.

The report, it should be added, omits any citation to the standards which were already on the books, including those which the Commission itself helped to frame in railroad reorganizations under the Bankruptcy Act. ${ }^{30}$

b) Lehigh Valley Railroad (February 7, 1949). ${ }^{\text {31 }}$-The Lehigh Valley was a relatively large carrier with a rather complicated capital structure consisting of perpetual annuity bonds, several issues of senior lien bonds having staggered maturities, several series of junior lien bonds of a distant maturity, and common shares. Pressure for a modification arose because of the imminent maturities of some of the senior lien bonds. The proposed plan was comprehensive: A maturity date would be placed on the perpetual annuity bonds, with no change in interest rates; the senior lien bonds would be extended for considerable periods without a change in interest rates; the junior lien bonds would be changed from fixed interest obligations into bonds on which three-fourths of the interest would be contingent on earnings and one-fourth would be fixed; and the junior lien bondholders would receive 19 per cent of the common shares outstanding after the modification. ${ }^{32}$ The ICC approved the plan (with an amend-

${ }^{28}$ The ICC notes that "the record shows that there are several routes, other than the applicant's line, available to the Seaboard, for the movement of its traffic on a basis which, the Seaboard contends, would be just as advantageous to it as moving traffic over the applicant's line ...."Id. at 382.

${ }^{29}$ An intervenor had pointed out that the plan did not even contain "any traffic or lease agreement between the applicant and its parent company to assure continued intercompany operation under proper safeguards for the bondholders." Id. at 383.

${ }^{30}$ In support of the position that the bondholders should receive a share of the equity, an intervenor had cited the Lehigh Valley plan which was then under consideration. The ICC's response was this: "In that plan there is a proposed award of stock to bondholders, a part of whose interest is made contingent on earnings. There is, however, no such proposed award of stock to bondholders whose bonds are proposed to be modified by extension of the terms without disturbance of interest provisions." Id. at $385 \mathrm{n} .2$.

31271 I.C.C. 553 (1949).

$32 I d$. at 556. Minor aspects of the plan, such as establishment of sinking funds, are not mentioned. In describing the various plans of modification, only the details required to support the discussion are noted. 
ment that the contingent interest on the junior lien bonds would cumulate for five rather than three years), ${ }^{33}$ finding that it was in the best interests of each class of security holders. ${ }^{34}$

An objection to the proposal by junior lien bondholders attempted to raise squarely the question whether the full priority precedents from other areas were applicable in railroad modifications. These intervenors argued that the plan does not observe "the judicial requirement that secured creditors must receive satisfaction of their claims before equity interests may participate in the residual assets or corpus of the applicant's estate." ${ }^{\prime 35}$ They contended, further, that if the proposed modifications are necessary, the present shareholders should be considered as having an equity which is without value. ${ }^{36}$ As a basis for this proposition they urged that in a bankruptcy reorganization shareholders would be eliminated if bondholders had their rights to interest changed from a fixed to a contingent basis or were given shares in place of their old debt obligations. ${ }^{37}$

The ICC was not unresponsive to these assertions. If one has difficulty in understanding the reply, the source of the trouble more likely is that in some respects the Commisions said too much rather than too little. The report properly points out that the intervenors were mistaken in assuming that in bankruptcy reorganization the shareholders of a railroad are eliminated where bondholders give up rights to fixed interest or receive shares. ${ }^{38}$ This correction

${ }^{33} I d$. at 593 . This amendment was made by the ICC on the ground that "the rights of the bondholders should be protected to the maximum extent possible consistently with sound financial practice and with the purpose of the act," and "such protection should reflect primarily the maximum allowable accumulations of interests. ..." Ibid.

${ }^{34} I d$. at 601 . The ICC mentions that there were a number of large institutional holders of the bonds, and, in identifying a witness, it indicates that there were small public investors. Id. at 577,583 .

${ }^{35} \mathrm{Id}$. at 579. These intervenors also contended that "section 20b of the Interstate Commerce Act is unconstitutional as taking the property of the [junior lien] bondholders without just compensation, as not constituting an exercise of a Federal power under the Constitution, and as being a delegation of legislative power without prescription of any standard for guidance." Ibid. The ICC's reply was that: "It is not within our province to pass on the constitutionality of a statute which we are required to administer. . . Section $20 \mathrm{~b}$... lays down in unequivocal language standards for our guidance. Whether the proposals constitute a tak!ng of properties would, as we see it, depend on the terms and conditions of the proposals, with such amendments as we find to be required, are just and reasonable." Id. at 589.

${ }^{36}$ Specifically, the intervenors contended that "the modifications do not observe the full priority rule since the proposal to make three-fourths of the interest on the [junior lien] bonds contingent is in effect an admission by the applicant that there is no reasonable probability that the earning power of the carrier is sufficient to pay the claims of its bondholders for principal and interest and leave a surplus for the stock." Id. at 579-80.

${ }^{37} I d$. at 590.

${ }^{38} \mathrm{Ibid}$. However, later in the report, to support its view that the compensation for the sacrifices of the common shareholders under the plan "must be in the advantages of avoidance of financial difficulties which it appears from the evidence might end in bankruptcy," the ICC says: "In such a proceeding, the common stockholders would be required to make the greatest sacrifice, either through curtailment or complete loss of their interest in the property." $I d$. at 595. 
is followed by what appears to be a fundamental announcement that the bankruptcy precedents on priorities are not in point anyhow:

The provisions of the [railroad modification] statute... contemplate consideration of the proposals from the standpoint of the interests of the various classes in a going business with due regard, among other things, to their contract rights and earnings possibilities. In Otis \& Co. v. Securities and Exchange Comm'n. ... a proceeding under the Public Utilities Holding Company Act, the [Supreme] court's decision contemplated valuation of the properties, for the purpose of determining the values of the rights of each class of securities, on the basis of a going business and not as though a liquidation were taking place, a situation similar in that respect to the proceeding now before us. Thus, in our opinion, the standards which we must apply in this proceeding to insure each class receiving just compensation for the rights surrendered may differ from these [sic] in a proceeding contemplating a liquidation of the carrier's property..$^{39}$

While the passage is somewhat garbled, it probably should be read as serving essentially to reject the view that in railroad modifications the rights of security holders are to be ordered and measured as though liquidation priorities were matured. There is the difficulty that the ICC slipped in construing the Otis opinion as calling for a going-business valuation of the properties of the corporation (which is the usual valuation method in bankruptcy reorganizations), whereas the opinion in fact calls for valuing its securities on a going-business basis (instead of looking to liquidation priorities). However, the ICC did not fall into the error of saying that the priority precedents under the Holding Company Act are directly applicable in railroad modifications. Adoption of these precedents would have been hard to defend. Readjustments under the Holding Company Act are forced by public policy in dealing with utility holding companies, while railroad modifications, at least some of them, as in the Lehigh Valley situation itself, are brought on by existing or prospective financial distress of the carriers. Thus the sound basis for paying little attention to default rights in the former situation does not have a counterpart in the latter. It might, in other words, be logical to recognize all the weaknesses of a particular senior security in measuring the rights of its holders in a public policy readjustment, but not equally logical to do so in a railroad modification where the weakness of the security might in part be due to the financial distress of the carrier, approaching the situation in which the default rights were sought as protection. ${ }^{40}$ There is a more direct reason for thinking that the ICC did not intend, in Lehigh Valley, to import any specific priorities doctrine from the Holding Company Act into railroad modifications. The Otis case dealt with measuring the claim which could be asserted by virtue of a preferred stock arrearage; the Lehigh Valley modification did not involve preferred shares at all. While the

${ }^{39} \mathrm{Id}$. at $590-91$.

${ }^{40}$ See Blum, The Investment Value Standard under the Railroad Modification Act, 45 IrL. L. REv. 357 (1950). 
SEC and later the courts extended the investment value principle of measuring claims (in Holding Company Act proceedings) to debt obligations, it never was applied to a weak bond retired for cash, and it was given only a most limited application to a weak bond exchange for other secutities. ${ }^{41}$ No one could reasonably believe that the ICC had in mind this latter unusual situation when in Lehigh Valley it referred to the Olis case.

Nor does the Commission's finding that the common shareholders have an equity in the existing capital structure of the road rest on the investment value doctrine of Otis. Such an equity was said to exist because the earning power of the enterprise was large enough to cover all prior demands on it and leave a residue for the common stock. ${ }^{42}$ This method of testing for an equity is not to be associated particularly with use of the investment value principle, especially as it is the usual one employed by the ICC in bankruptcy reorganizations.

But these observations invite asking why the Commission announced in Lehigh Valley that liquidation priorities are not decisive. There is no indication that the claim of a bondholder was treated as being different in amount from that which could have been asserted in an involuntary liquidation. ${ }^{43}$ It might be suggested that the Commission was responding to the contention that the junior bondholders would have obtained a larger share of the equity in a bankruptcy reorganization than under the proposed plan. To this point, however, one might have expected the reply to be that, if junior bondholders would receive a larger share in a bankruptcy reorganization, it is because the existing shareholders' equity presumably would be smaller if the financial condition of the road were so much worse as to necessitate such a reorganization. The least disturbing explanation is that the Commission, in rejecting liquidation priorities as governing in Lehigh Valley, was giving notice that it would not adhere to its bankruptcy reorganization formula for determining whether a class of security holders has received full compensation. The reference, under this view, was not aimed at how large a claim the junior bondholders could assert, but at the process for determining how much compensation they were entitled to receive for giving up rights.

Alongside the Commission's negative pronouncement that liquidation priorities are not controlling in section $20 \mathrm{~b}$ proceedings, there is a good deal of language in Lehigh Valley to the effect that each class of security holders is entitled to "just compensation" or "full compensation" "for the rights surrendered." "i4 Nowhere is this thought stated in a simple declaratory sentence as a general principle, but there are a number of passes in that direction. In several

4S See Billyou, Priority Rights of Securily Holders in Bankruplcy Reorganization, 67 HaRv. L. REv. 553, 577 (1954)

4271 I.C.C. 553,591 (1949).

${ }^{13}$ That is to say, a $\$ 1000$ bond apparently was treated as having a claim based upon its principal amount.

11271 I.C.C. $553,588,593,595$ (1949). 
places the Commission analyzes whether such compensation exists under the plan and then concludes that it is present. In the passage, previously quoted, referring to the Holding Company Act, the Commission talks of "the standards which we must apply in this proceeding to insure just compensation for the rights surrendered." 45

The analysis of what constitutes such compensation is skimpy. The ICC treats both the extension of maturity of the senior lien bonds, and the expected reduction of prior fixed charges through operation of a sinking fund for retirement of senior lien bonds, as being a part of the compensation for the rights surrendered by the junior lien bondholders ${ }^{46}$ The major part, however, obviously was the 19 per cent of the equity which they received. Although the opinion notes that the objectors asserted that these shares had a market value of $\$ 24$ per $\$ 1000$ bond, ${ }^{47}$ it does not disçuss their value or consider whether it might be other than the current market quotation. There is not a single clue as to why a transfer of 19 per cent rather than, say, 9 per cent or 29 per cent of the equity is proper in the sense that, together with the other "benefits" conferred on the junior lien bonds, full compensation is achieved. ${ }^{48}$

A few conjectures about this omission seem in order. It is possible that, having rejected liquidation priorities as controlling the magnitude of the bondholders' claims, the ICC could not locate another standard which would permit stating creditors' claims in dollar amounts-that is, in quantifiable terms. It is also possible that the Commission did not wish to place a dollar value on the shares to be transferred inasmuch as this presumably would require that a total valuation be placed directly or indirectly on the road, a process which might prove awkward in modification situations. Finally, and this perhaps is only restating the other possibilities, it is likely that where a better quality bond is being exchanged for an inferior quality bond plus stock, the Commission believes that the question of equivalency, and accordingly of full compensation, involves basically a comparison of qualities, and therefore an overall subjective judgmerit is all that can be made or expected. In this form the governing standard in railroad modifications might be stated as a vague sort of investment value doctrine coupled with the full compensation principle: A class of security holders is entitled to receive the full equivalent of its old securities ap-

${ }^{45} I d$. at 591.

${ }^{46}$ These changes are treated by the ICC as being part of the compensation on the ground that they "should materially improve the position" of the junior lien bondholders. Id. at 590 .

17 Id. at 589.

${ }^{48}$ The ICC does note that there was "undisputed testimony that it may be expected that very generally, and perhaps at all times, the contingent interest will be earned and paid throughout the remaining term of the bonds." Id. at 589-90. But this assumption does not contribute to understanding why $19 \%$ is the share of the equity which achieves full compensation for the junior lien bondholders. In this connection it might be noted that intervenors contended that (among other alternatives) they should receive $38 \%$ or even $49 \%$ of the total common equity. $I d$. at 580 . 
praised (qualitatively) as though no modification of the capital structure or liquidation of the enterprise were to take place. Such a standard might be intelligible, even though it would not give much guidance, and even though, for reasons already offered, one might regard it as perverse where the carrier is in substantial financial distress.

But the ICC apparently had no intention of announcing this suggested combination as its standard in railroad modifications, for the opinion goes off in another direction entirely. The intervening junior lien bondholders had contended that "no other class of creditors or [sic] the stockholders are required under the proposed plan to make any substantial sacrifice." ${ }^{249}$ In meeting this thrust, the Commission, instead of adhering to its full compensation line, reached for another theme: "the apparent sacrifice of the ... [junior lien] bondholders, as compared with that of the holders of the other issues of bonds is reasonable in the light of the fact that the lien of the mortgage securing ... [their] bonds is generally junior to the liens of the other bonds. So also is it reasonable in comparison with the greater immediate sacrifice required of the stockholders. ${ }^{350}$ If these be words of cheer to the junior lien bondholders, they are anything but comforting to those seeking orderly administration through establishment of principles.

Any doctrine of "reasonable comparative sacrifices" necessarily must be incompatible with any meaningful doctrine of full compensation. Sacrifice refers either to sacrifice before compensation (i.e., gross sacrifice) or to sacrifice after compensation (i.e., net sacrifice). The full compensation principle requires that any gross sacrifice by a class of senior securities be recompensed in full, so that they suffer no net sacrifice, before a junior class is allowed to participate; and if compensation is full, it does not matter, under the full compensation principle, how large is the gross sacrifice imposed on the senior class. It is simply nonsense to adulterate full compensation doctrine with the idea of comparative sacrifices. Without trying to guess what the contents of a comparative sacrifice test might be, it would seem to be only another term for relative priorities as contrasted to absolute priorities, or another name for a composition with creditors. ${ }^{51}$

There is no reason to believe, however, that the ICC was aware of the inconsistency. More likely it was following the ancient prescription that two reasons are always better than one. Perhaps this is what it had in mind in saying: "Obviously no definite formula can be outlined which should be followed in all cases under ... [the railroad modification] statute. We think that the provisions require a consideration of the best interests of the classes from all applicable

1) Id. at 592 .

so Ibid. The ICC elsewhere says that since the common stock is the most junior security, "it is reasonable that the holders should make the greatest sacrifice under the plan." Id. at $\mathbf{5 9 5 .}$

${ }^{31}$ The notion of relative priorities is hard, if not impossible, to distinguish from composition with creditors. But see Bonbright and Bergerman, Two Rival Theories of Priority Rights of Securily Holders in a Corporate Reorganization, 28 CoLJu I. Rev. 127 (1928). 
standpoints, including, without limiting the categories, the probable results of future operations, the effect of possible reorganization in bankruptcy or receivership and, in connection with the treatment accorded any class, the final effect of the proposal upon the interests of such class. The final result must be just and reasonable and fair to the classes inter-se."'52 This does announce, quietly, that not only amendments but the totality of a proposal must be just and reasonable and fair; but the emphasis seems to be that three reasons are better for the Commission than two. Then again, to give it the benefit of the doubt, the Commission might only have been asserting that different kinds of proposals, or proposals in different kinds of circumstances, should be governed by different standards. But, if so, we must keep watch to see whether we are ever told what categories the situations fall into and what standard is applicable in each.

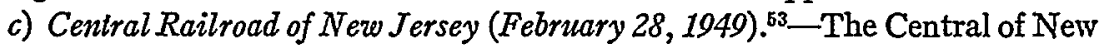
Jersey, a majority of whose shares were owned by the Reading railroad, was a relatively large carrier which, at the time of applying under section $20 \mathrm{~b}$, was in reorganization under Section 77 of the Bankruptcy Act. ${ }^{54}$ The proposal for modification was designed to take the road out of reorganization by curing the default on two series of its bonds, 55 maturing about 40 years later, on which there was an accrual of seven years' unpaid interest. Under the proposal: (1) a sinking fund for these bonds, and also a capital improvements fund, would be established; (2) interest on the two series would be reduced from 4 per cent and 5 per cent to $3 \frac{1}{3}$ per cent (an average reduction of almost one-third); (3) two years' accrued interest would be paid in cash and for the remaining past due interest bondholders would receive negotiable, secured, non-interest bearing certificates without a maturity date, to be retired (pursuant to a formula) out of earnings, either by redemption at face amount or by calls for tenders; and (4) one-half the total common shares would be given to the bondholders, subject to conditions which would prevent a shift of voting control from the Reading to

52271 I.C.C. 553, 591 (1948). The report deals very briefly with the interests of the senior bondholders. As to the annuity bonds, the ICC says that the benefits to the bondholders resulting from "[establishing] a fixed date for payment of the principal of the obligation, and premiums for redemption prior to maturity constitute full compensation for the rights surrendered." Id. at 588. As to the other senior bonds, whose maturities are extended, the ICC, after noting that the financial position of the road would be improved by the postponement, concludes: "[C]onsidering the high interest rates of the bonds to be extended ... the holders of these bonds are fully compensated . . f for the rights surrendered." Ibid. This point is examined in some detail later in the text, at p. 643 infra. There was no opposition to the proposal by senior lien bondholders or stockholders. Ibid.

53271 I.C.C. 501 (1948): The report was by the Commission. In this proceeding, the examiner filed a report, and the Commission disagreed in part with his conclusions. The reports in the two earlier cases discussed were by Division 4, the Finance Division of the Commission. All reports discussed subsequently were by the Finance Division, unless otherwise stated.

${ }^{54} I d$. at 502 . In addition to those owned by the Reading, shares were held by the public.

${ }^{55}$ The plan was formulated after negotiations with institutional holders of the bonds and a committee representing public ormers, Id, at 512. 
them unless, after six years, some of the interest certificates were still outstanding. While the interest certificates were conceived of as compensation for the accrued interest not paid in cash, the shares and sinking funds apparently were intended to offset the reduction in interest rates on the bonds. Objections were raised by shareholders other than the Reading, and some bondholders also intervened, apparently in support of the proposal. ${ }^{56}$ The ICC approved the plan as being, among other things, in the best interests of the bondholders and shareholders. .77

On the question of best interests, the opinion focuses on the combination of reducing interest rates on the bonds and giving shares to the bondholders, presumably because the objections centered on this unit of the package. The Commission considered both whether the bondholders are being overcompensated (as apparently contended by shareholders), or undercompensated (a position which might have been taken by bondholders). The possibility of overcompensation is disposed of easily. The present value of the reduction in interest, computed by discounting the future annual loss at the weighted average rate of interest on the bonds, is shown to be slightly more than the par value of the common shares allocated to the bondholders. ${ }^{58}$ With no hint of irony, the Commission then notes that the bondholders are not overcompensated by the shares since "the market value of the stock would not, under foreseeable circumstances, exceed its par value"59 inasmuch as no dividends could be paid on the shares for many years to come. Further, after some rapid but undisclosed calculations, the Commission observes that "the stockholders would be required to surrender at least one-half of their equity and possibly more in a [bankruptcy] reorganization." ${ }^{\text {"60 }}$

Of greater interest is the discussion whether the bondholders are therefore undercompensated. If the estimated earnings left over for the common stock (but subject to highly restricted application for many years) were capitalized "at 8 to 10 times for purposes of computing value of the new stock," the result would be "a theoretical value for the shares of stock [sic] allocated to the bondholders approximating the present value... of the fixed interest obligation proposed to be surrendered." "However, says the ICC, such a theoretical value

${ }^{56} \mathrm{Id}$. at 513 . On this page of the report it is said that two groups of intervenors opposed the proposal-a protective committee for stockholders, and the Inter-Municipal Group for Better Rail Service and the Jersey Shore Protective Committee, which represented municipalities served by the carrier. On a later page reference is made to "intervening bondholders," but these apparently were bondholders who supported the plan. Id. at 521.

${ }^{57}$ Id. at 524, 530. The ICC amended the plan to provide for cumulative voting in the future. $I d$, at 527 .

${ }^{58} \mathrm{Id}$. at $521-22$.

${ }^{59} \mathrm{Id}$. at 522 . The closing bid in 1948 for the existing shares was $31 \frac{3}{4}$, which would be equivalent to $15 \frac{7}{8}$ for the proposed new $\$ 50$ par shares. $I d$. at 525 .

${ }^{60} \mathrm{Id}$. at 526 . This thesis is explored more fully at p. $626 \mathrm{infra}$.

61 Id. at 522-23. 
"would be unreasonably high by comparison with the prevailing market prices of comparable common stocks, especially in the light of the restricted application of net income." ${ }^{\prime 2} \mathrm{It}$ is clear, moreover, that "in the foreseeable future, the annual return which the bondholders may receive [on the shares] appears to be inadequate to compensate them for the loss of their interest." ${ }^{33}$ At this juncture in the analysis the Commission concludes that "from the standpoints of return and probable immediate market value of the new stock, the new stock allotted to the bondholders does not constitute adequate compensation." ${ }^{14}$ But this is only the halfway mark. In a garbled passage the Commission notes that after many years, perhaps as many as twenty, the earnings and dividends on the common shares might reach a level at which "if such conditions should exist over a series of years probably the stock would sell at considerably above its ... par value." ${ }^{165}$ All this then leads up to the conclusion that "the bondholders would be without compensation for the rights surrendered for many years, with the possibility of full compensatiion later through receiving in full the amount to which they are now entitled, and compensation for the intervening loss of return through the enhanced value of the stock held." ${ }^{\prime 66}$

Surely this is remarkable reasoning. Taken literally it cannot stand scrutiny. If bondholders suffer an immediate decline in the value of their bonds, they are not made whole by receiving stock which in the distant future might possibly acquire a value equal to that lost now. Unless the shares are expected to rise to even higher levels in the future, their present value obviously does not match the present loss on the bonds. But apparently there could be no such expectation here since the Commission, as already noted, concedes that an "unreasonably high" ${ }^{\prime 67}$ multiplier of earnings would be required merely to bring the shares up to their par value, which in turn was less than the value admittedly lost by the bonds through reduction of interest rates. It might be tempting to suggest that we are on the wrong track and that the Commission was only saying, in a peculiarly roundabout fashion, that probable immediate market values should not be determinative in weighing whether full compensation is provided the bondholders. This explanation will not pass muster, however, for it requires torturing the whole structure of the Commission's argument, which undeniably is directed not at near-term but at long-range considerations of value.

These difficulties aside, what does the report add to our knowledge regarding the standard for acceptable exchanges? There is no explicit discussion of standards in the opinion, and it avoids citing precedents, not even mentioning Lehigh

${ }^{62} I d$. at 522 .

${ }^{63} I d$. at 523. "A witness testifying for groups of bond holders supporting the plan stated that the bondholders recognized this fact, but that they were relying upon the value of the shares ... to be received to make up the deficiency. Through retirement of debt, they expect the stock to increase in value." Id. at 523-24.

64 Id. at 523.

${ }^{66} \mathrm{Ibid}$.

${ }^{65} \mathrm{Id}$. at 524 .

${ }^{67} I d$. at 522 . 
Valley. Thus at best we can merely draw a few uncertain inferences. One indicator that should not go unnoticed is that the ICC approved the plan without finding that the bondholders were fully compensated. On this score all that the Commission has to say is that there existed the "possibility" of full compensation, even though elsewhere on the same page it states that creditors must receive just and reasonable compensation for the rights surrendered by them. This finding is virtually a self-contradiction. Something which adds up only to a possibility of full compensation necessarily must fall short of full compensation. Perhaps an awareness of the deficiency prompted a passing return to the comparative sacrifices theme found in Lehigh Valley. The ICC observes that "while it would be necessary [for bondholders] to hold the stock throughout the period in which no dividends are paid in order to realize the full compensation, it is likewise true that the [old] stockholders would have to hold their stock for the same length of time to realize any substantial sum either in dividends or through sale of the stock." "The comparative viewpoint is repeated in the Commission's conclusion that, "thus as between these two classes of security holders we find the proposals to be just and reasonable."70 There is also in the report a slight touch of a motif which appeared in the Macon, Dublin \& Savannah opinion. Notice is taken that the dominant stockholder, the Reading Company, was in a position to divert a substantial volume of traffic from the applicant. ${ }^{71}$ Then in rejecting the suggestion that there be immediate cumulative voting for the common shares, an arrangement which could deprive the Reading of control, the Commission points out that "continuation of the present traffic relationship of the applicant and the Reading Company ... , under the provisions of the plan for policing such relationship, should inure to the advantage of all the stockholders, as well as to the advantage of the bondholders." 72 Three reasons, it seems, are still better than two.

But this is not the end of the ICC's teachings in the Central of New Jersey modification. A substantial number of the common shareholders would not assent to the original plan, causing a revision to be proposed. ${ }^{73}$ As changed, three instead of two years' back interest on the bonds would be paid in cash, with a corresponding reduction in the amount of interest certificates to be distributed to the bondholders; moreover, the fraction of the equity to be allocated to the bondholders was reduced from 50 per cent to 40 per cent of the total. No one who participated in the earlier proceedings entered an objection to the revamped proposal, which resulted from "negotiations between" the various interests. ${ }^{74}$ In a decision four months after its original report, the Commission again made the affirmative findings required by the statute for approving a

${ }^{88} I d$. at 524.

BD Ibid.

${ }^{72} I d$. at $526-27$.

${ }^{70}$ Ibid.

${ }^{73} \mathrm{Id}$. at 692.

${ }^{71}$ Id. at 516, 526.

71 Id. at 693 . 
plan, ${ }^{75}$ and again did so without offering a single citation to precedents bearing on our inquiry on standards.

Of course the interesting question is how the Commission could logically conclude that both plans were in the best interests of the bondholders. If in the original plan there was only the "possibility" of full compensation for the surrender of annual interest, how could there be even that degree of recompense in the revised plan where the bondholders' share of the equity was reduced by 20 per cent? It would be stretching things a bit to say that the Commission answered this question; but the second opinion did include two lines of thought which might have been addressed to it. One was a restatement that there were benefits to be derived by the company, and hence the bondholders, from continued traffic relations with the Reading Company, and to emphasize that "there is no assurance that this .. . relationship would be continued in the event the applicant's proposals are not adopted." "76 But this point could not be good for much mileage, especially since it was advanced in the first report as a distinctly minor factor. The other consideration is even more elusive. The Commission records a witness for the bondholders as testifying that the amount by which the value of the additional cash (in payment of one more year's past due interest) exceeded the value of the interest certificates replaced by the cash, was about equal to the expected maximum loss on the market price of the bonds attributable to the proposed reduction in interest rates. ${ }^{77}$ If so, the package to be received by the bondholders under the revised plan is, presumably, the substantial equivalent of that called for by the original plan, and therefore the new plan is no less acceptable.

To do justice to this reasoning we must turn to an aspect of the original report that was previously omitted from our review, that dealing with the propriety of trading the seven years' overdue interest for cash in payment of two years' accumulation and for non-interest bearing certificates to cover the balance. The Commission thought this swap all right, apparently for the reason that the "applicant's present cash position does not permit the immediate payment of this arrearage of interest in cash...."78 However, at the time the revised plan was put forward the applicant seemingly was able to pay a larger fraction of the arrearage in cash immediately. Under the ICC's earlier reasoning, paying the bondholders this additional cash (and distributing correspondingly less certificates) for their arrearage would not give them anything to which they were not already entitled. It follows that the revision of the arrearage swap did not yield the bondholders any bonus. And absent such an "extra" on the back interest part of the deal, there was nothing to compensate them for losing 20 per cent of the equity which they would have received under the original plan for the

${ }^{75}$ Id. at 699 , 703. The Supplemental Report is also by the Commission.

${ }^{76} I d$. at 699.

${ }^{77} I d$. at 698 .

${ }^{78} I d$. at 521. 
reduction in their annual interest claims. ${ }^{79}$ But apparently nobody informed the Commission on these matters.

d) Atlantic \& Danville Railway (March 30, 1949). ${ }^{80}$-The Atlantic \& Danville was a small carrier, all of whose stock was held by three trusts in England, ${ }^{81}$ and whose issues of 4 per cent first and second mortgage bonds, apparently held by the public, ${ }^{82}$ had matured shortly before the application for modification was made. Its plan was to pay $\$ 400$ and $\$ 250$ in cash on each $\$ 1000$ first and second mortgage bond, respectively; to issue new 3 per cent first and second mortgage bonds, due 50 years later, in substitution for the unpaid principal of the old first and second mortgage bonds, respectively; and to give 43 per cent of the total equity to the bondholders, the first mortgage claimants to receive two shares and the second mortgage claimants one share for each $\$ 1000$ bond. ${ }^{83}$ There apparently were no objections to the proposal as finally drafted..$^{84}$ It was approved by the ICC with an amendment that for the first five years all interest on the new bonds would be contingent instead of fixed, with cumulation limited to three years. ${ }^{85}$

In analyzing the proposal as it affected the first mortgage bondholders, the ICC framed the main question quite precisely: "Since the first-mortgage bonds [had] matured ..., the problem is to determine the reasonableness of the compensation to the holder of each $\$ 1000$ bond for reinvestment of $\$ 600$ for a term of 50 years at a rate of 3 percent. ${ }^{1886}$ No exception can be taken to this formulation. The Commission moved immediately to the propositions that "doubtless the 3 percent rate is too low for a first-lien bond of an independently operated property as small as the applicant," and that "an annual return of 4 percent would be reasonable under the circumstances." able" in this context was left in doubt. Did the Commission mean that a 4 per cent bond could reasonably be expected at some time in the unspecified future to sell at par? Or that it would probably sell at par soon after issuance? Or that comparable railroad bonds then outstanding carried 4 per cent coupons, though

79 It might be noted that a witness for the bondholders testified that "the bondholders were of the opinion that the present stockholders were entitled to an equivalent [sic] for the benefit [i.e., the payment in cash of one year's interest] which the bondholders would receive under these proposed amendments." Id. at 698.

${ }^{80}$ Southern Ry. Abandonment, 271 I.C.C. 605 (1949). The report on the modification is included in a report in an abandonment proceeding in which the Southern Railway Company sought permission to abandon operations of the line owned by the Atlantic \& Danville Railway Company.

${ }^{81}$ Id. at 635.

${ }^{82}$ This is based on the fact that $75 \%$ of each issue was not held by fewer than 25 holders. Id. at 646.

83 Id. at 630-34.

${ }^{84}$ Committees for the first mortgage and second mortgage bondholders supported the plan. Id. at 634 .
${ }^{85} I d$. at 651 .
${ }^{86} I d$. at 640 .
${ }^{87}$ Ibid. 
at the time they might be selling at substantial discounts? Perhaps a clue that the Commission intended to say that the first-mortgage bondholders were not entitled to new bonds which could be expected to sell at par soon is furnished by a citation to Lehigh Valley, to the effect that liquidation priorities are not necessarily the standard for just compensation in railroad modifications. ${ }^{88}$ In the case of these first-mortgage bondholders, however, this reference seems inapposite. Even if it be granted that liquidation priorities are not to be treated as matured by a modification, that conception could have no proper application where, as here, the first-mortgage bonds had already matured naturally and the debt was adequately covered by the value of the enterprise.

With a 4 per cent return as the test, the proposed new 3 per cent bonds were obviously inadequate compensation, and under the plan the only possibility for overcoming the 1 per cent deficiency lay in the two common shares to be given on each $\$ 1000$ bond. This allocation was on "an agreed basis, not reached by any formula or mathematical calculation." mission played down the fact that at the time the shares had merely a "nominal" value. ${ }^{90}$ It noted that in the near future, since no dividends would be paid on the shares because of an impending improvement program, the bondholders would get only a 3 per cent return, ${ }^{91}$ but emphasized that on the applicant's forecast of earnings, the two shares and the new bond combined would earn 4.15 per cent after completion of the improvements in the distant future..$^{92}$ On this basis it thought that the "future earnings of the applicant may be expected to afford these bondholders a reasonable return." 93 Apparently, however, it detected a weakness in the point since the earnings on the shares "may be subject to fluctuations," the "value of such stock," are realized. ${ }^{96}$ (Later, in another connection, it indicated that the stock might reach "possibly $\$ 25$ per share," and probably "somewhat less than $\$ 40$ per share" after twenty or more years of operations. ${ }^{97}$ ) In thus reassuring the bondholders, the Commission seems to have been double counting. If the possibility of an increase in value of their shares is part of the bondholders' compensation, earnings on those shares cannot also be counted as compensatory, since one is a function of the other ${ }^{98}$ In any event, it might be noted that the Commission

${ }^{88} \mathrm{Id}$. at 641 .

${ }^{89} \mathrm{Id}$. at 639. It was testified that "none of the negotiating parties took the position that the present stockholders should surrender to the bondholders a majority of their stock." Ibid.

${ }^{s 0} I d$. at 643 .

s1 $I d$. at 641 .

${ }^{2}$ Ibid.

${ }^{93}$ Ibid.

94 Ibid.

${ }^{95} I d$, at 642 .

${ }_{98}$ Ibid.

${ }^{97} I d$. at 643 . This observation appears in the part of the report dealing with the interests of the stockholders.

${ }^{98}$ The ICC indulged in a comparable line of reasoning in the Central of New Jersey proceeding. See 271 I.C.C. 524 (1949). 
did not find that the first-mortgage bondholders received full compensation, but only that they got "adequate compensation," for the rights surrendered. ${ }^{99}$

The ICC's analysis of the position of the second-mortgage bondholders under the plan is quite different. It is observed that using the company's earnings estimate, they will obtain a 4 per cent return, "to which their present holdings of bonds entitle them," "only when earnings exceed the estimates considerably."100 There is no indication why the owner of a naturally matured 4 per cent second mortgage bond is entitled to a 4 per cent yield, unless it is on the same ground, previously indicated, that the owner of a matured 4 per cent first mortgage bond is entitled to a 4 per cent return. But such an apparent equivalence in treatment would be unwarranted, anyhow. If 4 per cent is the prevailing or proper rate (of coupon or yield) on first mortgage bonds under the circumstances, then the corresponding figure for second mortgage bonds must be higher because they are riskier. Therefore, if we pursue the logic imputed to the Commission in setting a 4 per cent rate as reasonable compensation for the senior lien bondholders, the second mortgage bondholders obviously would be entitled to a rate above 4 per cent. It might be suggested that the Commission thought that both classes of bondholders were entitled to 4 per cent simply because their old bonds were 4 per cent obligations, regardless of current yields and coupon rates on comparable securities. This explanation, however, conflicts with its analysis for the first mortgage bonds, and the Commission expressly took a different course in analyzing the position of the second-mortgage bondholders. The fact that they will not earn 4 per cent under the estimated earnings should not "control our considerations," it says, "since... [the old] bonds have matured." 101 Instead, it argues as follows: "In a liquidation ... [these bondholders] would be fortunate to receive any substantial return on their investment, and in any [bankruptcy] reorganization they would be required to accept largely income bonds and stock in exchange for their present holdings. Probably such securities on their face would permit payment of income to these bondholders greater than the fixed-interest 3 per cent bonds and stock allocated under the proposals. But from the evidence we conclude that the probabilities are that the income from the securities bearing contingent interest and entitled to dividends when declared would not exceed the fixed-interest requirements and dividends which may be declared on the securities allocable under the proposals." 102 On this ground the Commission reaches the finding that the plan is "just and reasonable" as to the second-mortgage bondholders. ${ }^{103}$

The analysis offered certainly seems promising for the development of a standard for acceptable exchanges in modifications. A minor difficulty can be dismissed lightly. The Commission says that the rate for the old bonds does not

${ }^{99} 271$ I.C.C. 605,642 (1949).

${ }^{100}$ Ibid.

102 Ibid.

${ }^{101}$ Ibid.

${ }^{103}$ Ibid. 
control "since ... [the] bonds have matured."104 Taken literally, the bondholders would have fared better-presumably they would have been entitled to a 4 per cent return-if their obligations were still far from maturity. Such a result would be perverse: Surely the owner of a weak bond that has already matured should be in a better position than the owner of a comparably weak bond which has a long life ahead. A literal reading here cbuld not have been intended. Another difficulty with the analysis is less readily charged to a slip of the pen. There is at least a strong overtone that the treatment to be accorded the secondmortgage bondholders under the proposed modification is all right because, if the road were to be reorganized in bankruptcy, they would be short-changed in any plan which the Commission is likely to approve. In other words, the only alternative to a modification is a reorganization in which the old stockholders would be permitted to participate even though these bondholders would receive far less than a hundred cents of real value on the dollar. To avoid such awkwardness, the analysis might be interpreted as indicating that the bondholders would not receive larger earnings on securities given them in a bankruptcy reorganization even though the old shareholders were eliminated from the company. ${ }^{105}$ But the comparison would then seem to reach a wrong conclusion. If the second mortgage bondholders were to end up with a larger share of the carriers' earnings than under the proposed modification, they presumably would be better off in a reorganization.

This relationship underscores still another difficulty. In a sense the crucial question is how large a fraction of the equity should be given to the bondholders in the modification. On this issue the report, mirroring the handling of the similar problem in Lehigh Valley, is bare of analysis. The closest one comes to understanding the basis for the proposed split of the equity is to be found in testimony of the applicant's counsel that "the stockholders [sic] offer to assign two shares of stock for each $\$ 1,000$ first-mortgage bond and one share for each $\$ 1,000$ second-mortgage bond immediately caught the sensibilities of the negotiators as to reasonableness, equitability, and logic."106

Subjecting the analysis to such close scrutiny may be unfair. Conceivably the Commission intended its words to have a different and more general thrust: In a modification, creditors are not entitled to receive any more than they would obtain if they took over the enterprise in a bankruptcy reorganization; and if in a modification the aggregate of the company's securities is more valuable

${ }^{104}$ Ibid.

${ }^{105}$ Note that in Central of New Jersey, the ICC remarked in effect that the stockholders would not have fared better in bankruptcy reorganization than under the proposed plan. 271 I.C.C. 501, 526 (1949). The same observation is made with respect to the stockholders in Atlantic \& Danville, 271 I.C.C. 605,644 (1949). But the point obviously has a different thrust when applied to bondholders.

$106 I d$. at 643. 
than in a reorganization, the differential belongs to the stockholders. ${ }^{107}$ Such a doctrine would parallel the common version of the "best interests of the creditors" standard in compositions or arrangements in bankruptcy, under which creditors are only entitled to get substantially as much as they would receive in a bankruptcy liquidation. Of course it usually is easier to predict what liquidation in bankruptcy will bring than to forecast how creditors will fare in a railroad reorganization. For the ICC, however, the latter task is not insuperable, inasmuch as it can dominate the reorganization process. Particularly in a situation where reorganization is imminent, or the rights of creditors have matured, such a standard for modifications might well be defensible and in harmony with the pronouncement that liquidation priorities are not necessarily applicable in modifications. One can only regret that the Commission did not either accept or reject it explicitly, but instead imposed on the reader's inventiveness.

e) Montana, Wyoming \& Southern Railroad (July 21, 1949). ${ }^{108}$-The Montana, Wyoming \& Southern was a very small road, having a recently matured issue of bonds, which had carried 3 per cent fixed interest and 2 per cent contingent, non-cumulative interest, and which apparently was held by the public. ${ }^{109}$ Its proposal was to pay $\$ 150$ in cash on the principal of each $\$ 850$ bond and extend the remainder for ten years, on the old interest basis. No opposition was offered, and the trustee under the bond indenture supported the plan. ${ }^{110}$ Noting that if the plan were consummated, the road would have extra cash which it intended to use for purchasing bonds whenever it could do so at a favorable discount, the ICC amended the proposal in several respects, to make it just and reasonable as to the bondholders: ${ }^{111}$ The cash payment of principal was increased from $\$ 150$ to $\$ 350$ per $\$ 850$ bond; the contingent interest was made fully cumulative to prevent use of surplus earnings of any year for acquiring bonds at a discount; and a sinking fund to retire the bonds was added. With these amendments the plan was approved.112

${ }^{107}$ This suggested position should be compared with that taken by the ICC in the reorganization of the Florida East Coast Railway under Section 77 of the Bankruptcy Act. There the Commission found a plan to merge with the Atlantic Coast Line unfair in part because the face amount of Atlantic Coast Line securities to be given Florida East Coast security holders was less than the face amount of new securities which the Commission presumably would authorize in an internal reorganization of the Florida East Coast. However, and this is the important point for present purposes, the aggregate market value of the Atlantic Coast Line securities to be received under the merger plan substantially exceeded the total market value which reasonably could be expected in the near future for the securities which would emerge from an internal reorganization of the Florida East Coast. 282 I.C.C. 81, 158-59 (1951).

${ }^{109} 271$ I.C.C. 779 (1949).

109 On the basis of the report, public holding can be inferred from the fact that the preferred stock was listed on the Boston Stock Exchange and 75\% of the shares were not held by fewer than 25 holders. Id. at 792.

${ }^{110} \mathrm{Ibid}$. The issuance of a proposed report after the hearing was waived by all the parties.

${ }^{111}$ Id. at 787-90.

112 Id. at 790-91, 795 . 
The amended proposal, although uncontested, raises the same question that was specifically put into issue in Macon, Dublin \& Savannah, the first reported proceeding under the railroad modification law: Are the bondholders entitled to compensation for an extension of their bonds? In that early opinion the Commission pointed out that the extended bonds were to be strengthened through addition of a sinking fund and restrictions on dividends; but in finding that the plan was in the best interests of the bondholders, it relied primarily on the fact that the earning power of the road depended in substantial part on the business generated by the parent carrier. ${ }^{113}$ Here, on the contrary, there was no such dependency. One thus might infer from approval of the plan that, at least under some unrevealed circumstances, a mere extension need not be accompanied by any compensation, perhaps other than a mild strengthening of the bonds as extended. On this basis, the dependency factor in the Macon, Dublin \& Savannah situation was unnecessary to the result reached, although it there was characterized as "more important" than the bond strengthening.

These reflections, however, are not to be found in the Montana, Wyoming \& Southern report. Not only does it fail to recognize possible inconsistencies, but it is without a single citation to any of the earlier opinions. In fact it does not even talk in terms of full compensation. Viewed most charitably, its contribution to the development of any-doctrine pertinent to our inquiry is nil.114

f) Maine Central Railroad (February 20, 1950). ${ }^{115}$-The application of the Maine Central brought forth the first report of the ICC under section $20 \mathrm{~b}$ to cope with an arrearage on preferred shares; all of the five earlier opinions which we have explored dealt either with an extension of debt maturities or a reduction of fixed charges on debt securities. Maine Central was a relatively large carrier, with a considerable bonded indebtedness not in default, whose 5 per cent cumulative $\$ 100$ par preferred shares ${ }^{116}$ bore an arrearage of $\$ 85$ a share, no dividends having been paid for over eighteen years. With the intent of putting its preferred stock on a current dividend basis, and thereby permitting payment of dividends on its common shares, the company proposed to capitalize the arrearage by issuing 4 per cent cumulative $\$ 185$ par shares in exchange for the old 5 per cent shares. A preferred shareholders committee, representing about half the outstanding shares, objected, suggesting instead that $\$ 5$ in cash be paid on each old share and the arrearage be capitalized with a new 5 per cent cumu-

${ }^{113}$ See text at p. 611 supra.

${ }^{114}$ Regarding the stockholders, the ICC concludes that the plan would be in their best interest inasmuch as their "equity would be further increased by the proposed reduction in funded debt, and the resulting reduction in fixed charges and the proposed postponement of the maturity of the remainder of the debt." 271 I.C.C. 779, 790 (1949).

115275 I.C.C. 261 (1950). The conclusions of the Finance Division differed from those of the examiner.

${ }^{116}$ The shares were publicly held. 
lative preferred.117 The ICC refused to approve the proposal on the ground that it fell outside the scope of the railroad modification law, inasmuch as it would not promote any of the policies set forth in the preamble. A prominent finding in this connection was that "instead of improving the applicant's financial position and its credit generally, the proposal ... might have the opposite effect."118 There was no showing that the marketability of the road's securities would be impaired because of continuing accumulations on the preferred stock; but rather it appeared that the existing arrearage could be reduced without recourse to a modification. ${ }^{119}$ The record also failed to disclose that the plan "would be in aid of the public interest." 120 To the Commission it seemed obvious that the proposed modification would serve chiefly the interests of holders of the common stock, almost 47 per cent of which was owned by directors and a relative of one director, through affording them "immediate access by way of dividends to the present accumulation of surplus and [the road's] prospective earnings." "121

Before finally disapproving the plan on this reasoning, the report contains material pertinent to our inquiry. It observes that, "the principles governing the modification of stockholders' rights under other Federal Statutes have been announced by the Supreme Court of the United States" in the Otis and Central Illinois Securities cases (dealing with the Public Utility Holding Company Act) and the Schwabacher case (concerning a merger under the Interstate Commerce Act). ${ }^{222}$ After quoting from each of these cases, it goes on to state that they "make it clear that the preferred shareholders for the purpose of these proceedings are not entitled as a matter of right ... to receive ... [for their arrearage claim] money and/or property which ... will ... become worth $\$ 85$ per present preferred share."123 Rather, they are entitled "to the equitable equivalent of the investment value of their claim on a going-concern basis."124 Thus the Commission returns to a theme found in Lehigh Valley and Atlantic \& Danville, this time with respect to a preferred arrearage, which, it should be recalled, was the object of the controversy in the Otis case.

Whether the proposed new security is the equitable equivalent of the investment value of the old preferred claim would turn on the comparison of two amounts. One is the present value of a $\$ 185$ par claim (preferred on liquidation),

117275 I.C.C. 271,266 (1949). The committee took the position, in the alternative, that no modification was necessary. A holder of general mortgage bonds also opposed the plan, on the ground that the "applicant has substantial obligations maturing in the near future and that neither its present nor future cash position will be sufficient to pay these obligations as they mature." Id. at 267.

118 Id. at 285.

119 Ibid.

${ }^{120} I d$. at 287.

121 Ibid. For a sequel to the ICC's refusal to approve the plan, see 307 I.C.C. 47 (1959).

12275 I.C.C. 261,271 (1950).

${ }^{123}$ Id. at 272.

121 Ibid. 
yielding 4 per cent in perpetutity; the other is to the combined present value of a $\$ 100$ par claim (also preferred on liquidation) yielding 5 per cent in perpetuity, plus the present value of an $\$ 85$ arrearage which can be paid off only over future years. To make this comparison the Commission says it "must consider, among other things, past yields, present market value ... future prospects of the stock ... [and] the applicant's past, present and prospective earnings." ${ }^{225}$ Just how (or why) all these factors would be taken into account remains unstated because the formulation is almost immediately changed. Reliance instead is to be placed largely on earnings since in the case of this company past yields have been controlled by the common stockholders through their board of directors, and present market values are based on judgments of investors about the probability that the application will be approved or, if it is not, that the directors will then undertake to liquidate the arrearage. ${ }^{126}$ One might ask in what circumstances these considerations would not be present when there is an arrearage. It turns out that we do not get to this question, nor do we learn how equivalency would be determined by relying principally on earnings. The whole subject is dropped because, without certain facts which were not introduced in the proceeding, the Commission was "unable to form any judgment as to the prospective net income which may be available for payment of dividends on the preferred stock." 127

Even without the additional information, however, the ICC concluded that the proposal is not in the best interests of the preferred shareholders. They were asked, the opinion says, "to yield their preferred position as to participation in the applicant's earnings available for dividends, while the holders of the common stock are asked to make no sacrifice whatever but are placed in a much more favorable position as to participation in such earnings." ${ }^{\prime 28}$ On initial impression this might seem to be a return to the comparative sacrifice theme which we have noted in earlier reports. If such was the intention, we should again ask whether the preferred do "sacrifice" anything if they receive the economical equivalent of what they give up, and whether agreeing to the payment of a larger annual sum in perpetuity to the preferred stockholders does not constitute a "sacrifice" for the common shareholders. One interpretation of the Commission's remark makes these questions unnecessary. It probably was only an oblique way of stating the familiar point that a dollar for dollar capitalization of an arrearage, without more, is usually a poor bargain for preferred stockholders.

${ }^{125}$ Id. at 281.

126 Ibid.

127 Id. at 282. The ICC therefore concludes that it was unnecessary to decide whether the plan should be modified as urged by the preferred stockholders' committee. $I d$. at 280 .

${ }^{128} I d$. at 283 . This statement by the ICC overlooks the fact that the plan in a sense did call for some sacrifice by the common shareholders: their rights to dividends thereafter would have come behind a preferred claim to $4 \%$ on $\$ 185$ par stock each year in perpetuity. 
g) Bangor \& Aroostook Railroad (A pril 18, 1950). ${ }_{.}^{129}$-With the application of the Bangor \& Aroostook, a relatively small carrier, the ICC again was confronted with a plan for extending debt obligations. The proposal would extend for twenty-five years the company's 4 per cent bonds, held in part by the "general public"130 and due to mature in about a year. These had never been in default as to interest or principal, and the fixed charges on them had been earned every year. During the extension, the interest rate would be increased to $4 \frac{1}{2}$ per cent, the bonds (some of which were already convertible into common shares on an unpromising basis) would be convertible into common shares on terms which had fair prospects of being attractive, and the issue would be strengthened by the establishment of a sinking fund to retire a substantial proportion of the principal before the new maturity date. ${ }^{131}$ No opposition to the plan was forthcoming, and the ICC approved it without amendment. ${ }^{132}$

As regards our inquiry, the report is most uninstructive. We are informed that, apparently as viewed by the Commission, the bondholders are being called upon to make a sacrifice in that they are asked to forego payment of principal for twenty-five years. ${ }^{133}$ In addition we are told that one witness testified that the proposed increased interest rate of $4 \frac{1}{2}$ per cent "exceeds that commonly established for first-mortgage fixed interest obligations in proceedings before the Commission," but "is less than the rate which might be obtained by the applicant in any new financing if that were feasible."134 Thus, in his judgment, the new rate "appears to represent a logical compromise between the necessity for compensating the bondholders for their sacrifice and the desirability of avoiding financial embarrassment, while doing so at reasonable cost under the circumstances." 135 We also are informed that the witnesses were unanimously of the opinion that the plan is "fair and equitable and in the best interests of the bondholders." ${ }^{\prime 36}$ Finally it comes as no surprise to learn that the Commissioners "so find." "137

But this is all we learn. There is no analysis or explanation why the ICC concurs in the conclusion of the witnesses. It is not even possible to ascertain whether the Commission accepts the view that the increased interest rate is a

129275 I.C.C. 369 (1950). ${ }^{130}$ Id. at 371 .

${ }^{131}$ A part of the proposal is omitted from this discussion. The Reconstruction Finance Corporation held all of an outstanding issue of Collateral Trust $4 \%$ bonds which would be modified under the plan. The RFC indicated "its willingness to consent to the . . plan." Id. at 370 .

132 Id. at 395.

${ }^{133} I d$. at 388.

${ }^{136} I d$. at 390 . It was initially proposed that the rate on the bonds be $41 \% \%$. "Primarily the change [to $41 \%$ ] resulted from a definite manifestation of the bondholders' belief that the lower rate would be insufficient to compensate them for giving up their early maturity." $I d$. at 389 . A number of witnesses testified that "with the higher rate they believe those bondholders will be fairly treated." Ibid.

${ }^{137} I d$. at 390 . 
"logical compromise." No cases or precedents are cited, and no effort is made to square the result reached here with the earlier proceedings in which an extension of debt was authorized without an increase in interest rate. ${ }^{138}$ Maybe the general atmosphere of harmony that prevailed prompted the Commission to say nothing which might disturb the peace.

h) Boston \& Maine Railroad (stock proposal) (April 19, 1950).139-The application of the Boston \& Maine, a comparatively large carrier, presented the ICC with the type of case previously confronted in Maine Central - a plan to eliminate arrearages on preferred shares. ${ }^{140}$ The new situation, however, was considerably more complicated. Three tiers of preferred shares were outstanding behind the company's debt. The top tier was a 7 per cent cumulative prior preferred, which had priority to dividends and in liquidation over all other preferred shares, and on which dividends were in arrears. The middle tier consisted of five (lettered) series of first preferreds with cumulative dividends ranging from $4 \frac{1}{2}$ per cent to 10 per cent; all of the five series were of equal rank in priority to dividends and on liquidation, and dividends were in arrears on all, but in different amounts due to the differential rates of dividend. The bottom tier was a 6 per cent non-cumulative preferred which was inferior to the other preferreds in priority to dividends and on liquidation. The plan was designed to both eliminate all the arrearages and simplify the equity structure. It provided for two new classes of stock -5 per cent convertible cumulative preferred and common shares. ${ }^{141}$ All of the new preferred was to be allocated to the old priorpreference shareholders; about 42 per cent of the new common would also go to the prior-preference shareholders, about 54 per cent of it would go to the five series of first-preference shareholders, and about 4 per cent to the old noncumulative preferred and old common shareholders. This plan drew objections from numerous interests, ${ }^{142}$ but was approved by the ICC with amendments, to be noted later, which altered the division of the new common shares. ${ }^{143}$

${ }^{138}$ See Macon, D. \& S. R.R. Bond Modification, 271 I.C.C. 376 (1948).

${ }^{139}$ Boston \& Maine R.R. Securities Modification, 275 I.C.C. 397 (1950). The Boston and Maine modification is described and analyzed carefully in MASson, New SHARES FOR OwD (1958).

${ }^{140}$ The various issues of shares were publicly held; however, in the case of the non-cumulative preferred, more than $75 \%$ of the total number of shares outstanding was held by fewer than 25 owners. $I d$. at 451 .

141 The plan first presented to the ICC, "and later withdrawn because of widespread opposition from certain stockholders groups," called for issuance of only one new class of (common) stock. $I d$. at 401 n.6.

142 Id. at 405-6. Some of the objectors contended (at least in the alternative) that no modification was necessary. Others opposed the proposal without offering amendments. Another advanced suggested amendments. These are not dealt with here because the details are not needed to support the discussion in the text. The application to the ICC stated that "assurances of assent" to the plan were given by varying percentages of the different classes, ranging from $43 \%$ to $76 \%$; but the validity of the percentages was challenged. Id. at 404 .

${ }^{143} \mathrm{Id}$. at 454 . A major issue in the proceeding was whether a modification was necessary. On this question the ICC concluded that "unless the applicant's equity securities are modified, accumulation of arrearages on the classes of stock on which dividends are cumulative, except 
As a preface to the Commission's views pertaining to our inquiry, it is important to understand the applicant's approach in working out the plan, as revealed in the report. In essence it involved these steps: $:^{144}$ (1) An estimate of normal future annual earnings was made on the basis of earnings during the past twenty years; (2) The estimate was capitalized at 5 per cent, a figure based on "a study of Commission decisions in [section] 77 proceedings, as well as on observation of the trend in recent years in the railroad industry"; ;45 (3) From this total capitalization there was deducted the principal amount of debt outstanding, in order to isolate the equity part of the capitalization; (4) The amount of the equity capitalization which could be represented by preferred shares was then computed by taking the maximum of estimated earnings after debt service which reasonably could be assigned to a preferred issue and capitalizing those earnings at 5 per cent; (5) These preferred shares, and the balance of the equity capitalization represented by common shares, were then allocated to the existing classes of equity securities. The allocation, "while declared to be primarily a matter of judgments," was in major respects predicated on a "mathematical method." 146 Basically, "the applicant's endeavor was to calculate what would take place in the future if the present capital structure were to remain in effect and then to translate the relative values so developed for the several classes of outstanding stock into the proposed new capitalization." 147

This "mathematical method" (which in essence mirrors that used in drawing up the Maine Central plan) ${ }^{148}$ can be illustrated by its application to the priorpreference stock..$^{49}$ A share's so-called "par value investment" claim (or "original investment" claim) of 7 per cent annually on $\$ 100$ par, is regarded as equivalent to $\$ 140$ par invested at 5 per cent, the rate on the new preferred shares. Its \$119 arrearage, given the estimated normal earnings, could be paid off in seventeen years if all estimated earnings after interest charges, current dividends on the prior preferred shares, and sinking fund requirements were applied to that undertaking $;{ }^{150}$ and when discounted at 5 per cent the $\$ 119$ arrear-

the prior preference, will continue with little prospect of liquidation for many years; that the proposed modification should result in enhancing the marketability of the applicant's stock and in increased stability of values of the modified securities, with resulting greater confidence therein of investors." Id. at 414 .

${ }^{144} I d$. at $424-26$. See particularly p. $426 \mathrm{n} .25$.

145 Id. at $424-25$.

147 Id. at 426.

146 Ibid.

${ }^{148}$ See text at pp. 629-30 supra.

149 Boston \& Maine R.R. Securities Modification, 275 I.C.C. 397, 427-28 (1950).

${ }^{150}$ One aspect of these calculations seems invalid. The amount of earnings available for clearing up the arrearage is computed after interest charges and sinking fund requirements, both of which are treated as constant throughout the years ahead. It would seem, however, that sinking fund operations would continuously reduce the total indebtedness and interest charges, and thus increase the balance of earnings available for paying off the arrearage. Since the arrearage could therefore be cleared up in a shorter period of time, its present value would 
age has a present value of $\$ 78.91$. Of this total claim of $\$ 218.19$, only $\$ 120$ would be satisfied by assigning all the new preferred issue to the old prior preferred class. Therefore, the balance of $\$ 98.91$ present value of a prior preference share is to be satisfied in new common shares.

If the formula were applied rigorously to all of the old equity issues, the noncumulative preferred and old common would get "practically nothing,"151 since there would be no possibility of dividend payments to them for at least seventyfour years. Under the proposal, however, they were awarded a small participation. This departure from the formula was made because "the applicant concedes that it is impossible to disregard completely the claims of their holders to some participation in the new capital structure," inasmuch as they do have voting rights and "they could not be expected to vote themselves out of existence." 152

For our purposes, the ICC's reaction to this approach and the resulting plan can be divided into four parts. In one part it strongly endorses, over a challenge, the use of the capitalized earnings method of reaching an over-all capitalization, citing as authority the leading Supreme Court precedents from other areas. ${ }^{153}$ Addressing the particulars of the applicant's computation, it observes that the income estimate "is at least on the optomistic side," estimate at a rate of 5 per cent might be regarded as excessive, and that the combination "certainly ... does not produce an unreasonably low capitalization in this case."155 One might easily infer that the total capitalization conceivably was too high, resulting in over-compensation of the junior interests. But apparently the Commission was not interested in exploring that possibility.

A second part deals with the intriguing problem of dividing up among the five series of first preferreds the shares of new common which had been allocated to that class as a whole. ${ }^{156}$ The proposed division took into account that varying arrearages would accumulate on the different series during the next seventeen years, the period in which the arrearage on the prior preferred presumably could be fully paid off; but it ignored their differential dividend rates in assigning investment values to the series for their "par value investment" claims, that is, for their rights apart from the arrearages. Instead of calculating these

seem to be larger than that calculated by the applicant and apparently accepted without question by the ICC. Moreover, the present values of the first (lettered) preferreds would also increase inasmuch as the assumed time for commencing payment of their current dividends and arrearages would likewise be advanced.

${ }^{151} I d$. at 429 . Discounted at a rate of 10 per cent, the par value investment claim of these stock issues would be about eight cents a share. $I d$. n.26.

152 Ibid.

${ }^{163} I d$. at $431-33$.

${ }^{154} I d$. at 436.

${ }^{155}$ Ibid. The ICC declined the opportunity to discuss the fixing of proper capitalization rates. Intervenors had asserted that "analysis of the decisions heretofore rendered by the Commission under section $20 \mathrm{~b}$ shown [sic] that in no case has the total capitalization of a railroad been reduced nor the rate of five percent used for capitalization purposes." Ibid.

${ }^{156} I d$. at $440-42,447-50$. 
investment values by capitalizing the annual dividend for each series in perpetuity after seventeen years, it was assumed that shares of each series would (apart from arrearages) have the same value-their $\$ 100$ par value-at the end of the seventeen years. To the objection that valuation of these rights should be based on the differential dividend rates, the Commission responded that "to do so would fail adequately to reflect the long period during which transactions would take place in the stock either through distress or for purposes such as control or manipulation of the market or corporate interests." $" 157$ The thrust of this point is not entirely clear. The ensuing discussion suggests that the Commission thought that, in the absence of dividends, the relative market values of the various series during and at the end of the seventeen years would turn on factors other than the differential rates for dividends; and that these prospective market differences, as well as relative market values in the past, should be taken into account. But then, in another difficult passage, the Commission says that the fact that all five series have the same par value should be recognized in computing their comparative investment values. The justification offered is that "although ... par value means little in connection with valuation of a stock," nevertheless "it constitutes the basic figure, representing at time of issue the value placed upon the assets of the corporation, justifying its issue."158 Presumably this idea is relevant to the problem at hand, but the nexus remains to be discovered. As to basing investment values on the dividend differentials, the Commission ultimately agrees with the objectors to an extent, on the ground that these differentials would, apart from arrearages, produce substantial differences in market values. Putting all this together, but not explaining how, it concludes that the spreads in the investment values of the series for their "par value investment" claims should be 40 per cent of those obtained by capitalizing the respective rates in perpetuity, and that the plan should be amended accordingly. ${ }^{159}$ Thus the "par value investment" claim of the 10 per cent first preferred is figured not at 200 per cent, but only at 140 per cent of the "par value investment" claim of the 5 per cent first preferred. Based on the Atlantic \& Danville report, we might have anticipated that the Commission would regard an even 150 per cent as more seemly. ${ }^{160}$

A third part concerns the fact that, apart from any arrearage, a share of prior preferred was assigned an investment value of $\$ 140$ under the proposal while it had a call price of $\$ 110 .{ }^{161}$ Not much space was needed by the ICC to arrive at a sound and sufficient justification for what seemed to be overcompensation of the senior preferred issue. Referring apparently to the investment value of the package to be received as well as of the securities to be given up,

${ }^{157} \mathrm{Id}$. at 448.

${ }^{159}$ The percentage was computed from the dollar figures given in the report.

160 See text at p. 626 supra.

${ }^{161}$ Boston \& Maine R.R. Securities MIodification, 275 I.C.C. 397, 447 (1950). 
it observes that "the value found, however, may not represent a market price at this time. ..."162 But then it goes on to say that "even if the values determined be considered as an indication of market value, thus apparently justifying limitation of the value of the stock to the $\$ 110$ call price, it is reasonable to allot to the prior-preference stock holders securities in excess of such values as compensation for surrender in part of their seniority."163 This pronouncement seems to conflict directly with the words of the Supreme Court in the Central Illinois Securities case, involving application of the investment value doctrine under the Public Utility Holding Company Act. "When it became apparent that the going-concern value [of the preferred issues] would exceed the call prices of the stocks by a considerable amount," the Court said, "the exact going-concern value became immaterial, because the call price, at which the corporation could always retire the preferred without reference to the Act, marked the limits of the preferreds' claims." ${ }^{164}$ Undoubtedly the ICC was aware of this precedent. Perhaps it felt free to utter its contrary dictum because the disparity between assigned values and market values in Boston \& Maine afforded a huge margin of safety.

In any event, the Commission approved the allotment of all the new preferred and some of the new common to the prior preferred issue as constituting the "equitable equivalent of rights surrendered." Implicit in the finding is the view that a dollar of value assigned to the new common is the equivalent of a dollar of investment value assigned to the old prior-preference shares (assuming that a dollar of the new preferred is equal to a dollar of the old prior preferred). If the valuation is realistic, this equation seems proper for it should not matter what form the dollar of value takes. ${ }^{165}$ We know, however, that the Commission thought that in this proceeding the overall capitalization on which the plan rested was optomistic, to say the least. ${ }^{167}$ From experience we also know that the water in an over-capitalization does not tend to be distributed proportionately among different classes of securities, tending rather to be more than proportionately prevalent in the new junior issues. Under the circumstances it indeed might be questioned whether a dollar of the new common is the equitable equivalent of a dollar of investment value ascribed to the old senior preferred. ${ }^{168}$

162 Ibid. ${ }^{103}$ Ibid.

${ }^{164}$ SEC v. Central-Illinois Sec. Corp., 338 U.S. 96, 145 (1949).

1es 275 I.C.C. at 447.

${ }^{166}$ See discussion of this point in Blum, Full Priority and Full Compensation in Corporate Reorganizations: A Reappraisal, 25 U. CHI. L. REv. 417, 434-36 (1958).

${ }^{167}$ See text at p. 634 supra.

${ }_{168}$ Another way of approaching this matter is through a comparison of capitilization rates. Estimated normal earnings were capitalized under the proposal at $5 \%$, producing a total capitalization of about $\$ 180,000,000$. Of this amount, about $\$ 97,000.00$ would be represented by the outstanding debt obligations, which on the average bore interest at about $4 \frac{3}{4} \%$ on the principal sum. The balance of the capitalization was to be represented by about 830,000 shares 
But, needless to say, the Commission never raised such a doubt; and no one should expect it to demand additional compensation for the senior preferred on the ground that the underlying valuation of the enterprise is unrealistically optomistic.

A fourth pertinent part of the report concerns the small allotment of new common to the old non-cumulative preferred and old common. ${ }^{169}$ The ICC, noting that these junior securities "have a legitimate, though small investment value," and citing the Otis case, declared that "their elimination would give undue weight to the rights of the various classes of security holders in a liquidation." 170 This ignores the fact that these juniors, as previously indicated, were to receive more than warranted on an earnings basis. ${ }^{171}$ There is no evidence that this troubled the Commission; but, having decided that some participation for the juniors was in order, perhaps it viewed the proposed allocation as being de minimis anyhow. In this respect a good precedent is furnished by the action of the SEC in allocating a generous though small participation to the old common stockholders in the proceeding which gave rise to the Otis case. ${ }^{172}$ Moreover, the ICC might have been agreeing with the applicant that some investment value (and a good deal of bargaining power) inhered in the junior issues because of their voting control. ${ }^{173}$

of a par value of $\$ 100$ each - a subtotal of about $\$ 83,000,000$. Of this amount, about $\$ 27,500$,000 would be in the form of the preferred shares, calling for dividends of $5 \%$ of par. Thus the balance of the total capitalization, about $\$ 55,500,000$ in common shares, would in effect reflect capitalizing the projected earnings attributable to these shares at about $51 \%$.

Given the liberality of the earnings estimate, a $\frac{1}{4} \%$ spread between the rate for capitalizing the earnings assigned to the new preferred and those attributable to the new common is patently inadequate. The risk associated with the common is obviously much greater than that applicable to the preferred. If 1.4 shares of new preferred is roughly the equivalent of one share of old prior preferred, then 1.4 shares of new common must be worth substantially less than one share of the old senior preferred. Perhaps the ICC had this in mind when it said that "for the surrender of their senior rights and of their priority for dividend accumulations, the holders of prior-preference stock, in addition to other above-mentioned benefits of a less tangible nature, will have, through the acceptance of new common stock, the prospect of greater return in the future than is afforded by their present situation." 275 I.C.C. at 444.

${ }^{169}$ Boston \& Maine R.R. Securities Modification, 275 I.C.C. 397, 428-29, 450 (1950).

170 Id. at 450 .

171 See text, p. 635 supra.

172 United Light \& Power Co., 13 S.E.C. 1 (1943).

${ }^{173} \mathrm{~A}$ fifth aspect of the report, dealing with the reshufling of voting rights under the plan, speaks for itself: "The applicant contends that, if the distribution of new stock is fair, then it follows that the resulting distribution of voting rights is fair, and, similarly, with respect to the possible effect of conversion privileges (which, if exercised, will further increase the voting power of the holders of present prior preference stock), if the inclusion of the same is fair, obviously the change in voting power is also proper, and that the increase in voting rights is a factor which, with other considerations, offsets the surrender of his prior position by the stockholder exercising his right of conversion. We agree with these views." 275 I.C.C. at 440 (1958). 
The Boston \& Maine proposal went through a second round, ${ }^{174}$ which is reflected in a report by the full Commission on reconsideration, ${ }^{175}$ issued about three months after the first report by the Finance Division. Several parts of the original report germane to our inquiry are elaborated or supplemented in this later opinion.

As regards the acceptance of the applicant's long range forecast of earnings, which an objector urged was too low, the full Commission observed that the "forecast represents the informed judgment of the applicant's officers, who are best qualified by reason of experience and knowledge to express opinion with respect to the traffic situation of the carrier."176 It then concluded that "their estimate of probable future income ... is the best evidence that could be produced." "177 Whether or not this is a correct assessment of the resources available to the Commission, it illustrates a condition which is manifest in many of the railroad modification proceedings. At least where an application is approved, the ICC appears to accept the earnings estimates of management without offering its own independent analysis of income prospects. Possibly this is a sound or even necessary administrative measure. Nonetheless it seems somewhat open to question where action is initiated by management and we might occasionally expect a bias in the direction of favorable estimates. Would not the whole procedure be improved if the ICC called or consulted its own witnesses or experts and reported their testimony even though it has great confidence in representatives of the management?

The second round also reconsidered the propriety of going beyond a discounting of prospective future dividends in arriving at the relative investment values (apart from arrearages) of the five series of first preferreds. In sanctioning the hybrid approach taken by the Finance Division in the original report, the full Commission emphasizes that "sole reliance cannot be placed on discounted payments" because of the great uncertainty whether the payments will be made. ${ }^{178}$ While the point, as noted before, may be valid, the second report is no more helpful than the first in explaining the process which replaced the straight discounting method. A good guess is that the Commission thought that exposition was practically impossible. If so, a principal hurdle is that no effort was made in either report to quantify the degrees of uncertainty associated with the prospective dividend payments, or to discuss what discount rates are appropriate under the circumstances. By this omission the Commission buried the key judgments it was making in valuing the various claims, and thus considerably increased the inaccessibility of its conclusions to analysis or criticism.

${ }^{174}$ There was also a third round, but it dealt only with the question whether certain assents to the plan were validly obtained and whether the requisite statutory percentage of assents had been secured. In a second Supplemental Report, the full Commission decided both issues in the affirmative, but one commissioner thought there was a shortage of assents to make the plan effective., 282 I.C.C. 750 (1953).

${ }^{175} 275$ I.C.C. 527 (1950). $\quad{ }^{177} \mathrm{Ibid}$.

${ }^{176} \mathrm{Id}$. at 535. 
The one discount figure which does appear in both reports is the 5 per cent rate used to compute the present value of the current dividend and the arrearage claims of the prior preferred, as well as the par-in-seventeen years and the arrearage claims of the first preferreds. ${ }^{179}$ Since this rate obviously plays a significant role in working out the allocation of securities among the classes, we need to consider its origin and propriety. We are informed by a footnote in the second report that, in connection with evaluating the current dividend (or "par value investment") claim of the prior preferred, a 5 per cent capitalization rate was employed because the plan proposes "to satisfy the major portion of the original [i.e., the par value investment] claim of this stock with a new 5 per cent preferred stock."180 This justification is well founded to the extent that $\$ 140$ par of new 5 per cent preferred is given in exchange for $\$ 100$ par of 7 per cent old preferred since both yield $\$ 7$ a share annually and are about equally well protected. But the 5 per cent rate loses this obvious foundation to the extent that the original investment claim of the old preferred is being satisfied in common. The question then is whether one dollar of original investment claim of the old preferred is the equivalent of one dollar of value assigned to the new common. ${ }^{181}$ Only by a mere coincidence could the fact that the new preferred carried a 5 per cent dividend rate have any immediate bearing on this question; and as indicated before, it seems most unlikely that a dollar amount of new common equalled a dollar of original investment claim of the old senior preferred.

A related question, likewise not discussed in the report, is whether the same discount rate should be employed for evaluating both the "par value investment" claim and the arrearage claim of a preferred stock. If 5 per cent is appropriate for the former is it equally so for the latter? The answer is not altogether certain. In the affirmative it can be argued that the two claims are of equal rank in a liquidation and so should be valued alike. But then liquidation priorities are not controlling in railroad modifications. It can also be contended that a single discount rate is proper because both claims are subject to identical risks in a going enterprise. This position, however, overlooks the fact that earnings would be applied to pay current dividends before they are available to clear up an arrearage. Hence, in arriving at present values, an arrearage is to be discounted at a higher rate because there is less assurance of earning income to cover its payment. While this point probably should be controlling, an argument can be made that, in allocating participation between a preferred and a common issue, an arrearage ought to be viewed as a risk-free investment in the enterprise and therefore discounted at the prevailing government bond rate of interest. The premise is that the arrearage is an involuntary investment in the firm, forced upon the preferred shareholders by the inability of the management, representing the common shareholders, to earn sufficient income to keep

${ }^{179} I d$. at $427-28,436,442,449,537-39$.

${ }^{180}$ Id. at 539 n.6.

${ }^{181}$ See discussion at p. 636 supra. 
current on payment of preferred dividends. Whether or not there is merit to this point, it seems never to have been considered by the ICC.

The action of the Commission in approving the proposal was sustained by the district court. ${ }^{182}$

i) Missouri-Kansas-Texas Railroad (bond proposal) (June 2, 1950). ${ }^{183}$ The modification proposed by the Missouri-Kansas-Texas, a relatively large carrier, concerned substantial accumulation of unpaid interest on bonds not in default. ${ }^{184}$ Interest payments on these junior bonds, which did not mature before another seventeen years, were dicretionary, but unpaid interest was fully cumulative and at maturity in effect was to be treated as an addition to principal. For five years prior to the application, the company had been liquidating

${ }^{182}$ Sakis v. United States, 103 F. Supp. 292 (D.D.C. 1952). In their complaint, the plaintiffs first alleged that there was "no evidence in the record to support the Commission's finding that the Railroad's plan meets the statutory test." Id. at 301. The court took the position that: "It is the duty of this Court to determine whether there is sufficient evidence in the Commission's record to justify its findings. That being done, our work is completed." Id. at 302.

The argument of the plaintiffs in opposition to the finding of the Commission that the plan is in the best interest of each class of shareholders was that "the plan is manifestly inequitable. In reassigning equity interests, the ... prior preference stockholders were favored to the detriment of the members of the junior classes." Id. at 302. The response of the court was that "in determining what values and interests were to be assigned to each class of stockholders under the plan, the Commission proceeded along traditionally approved lines." Id. at 302.

The plaintiffs also contended that "Congress failed to prescribe standards for the Commission to follow in determining the rights of the senior and junior stockholders." Id. at 310 . The court, in rejecting this contention, said: "Of necessity, the statute could not spell out with more particularity the method by which the Commission will reach its determination as to how many new securities will be issued to each stockholder. The existing capital structure, as well as the proposed, peculiar to each carrier, will necessarily result in different arrangements on the issuance of securities. The Court has already indicated that the procedure followed by the Commission in determining the amount of the Railroad's new total capitalization and the allocation of new securities to the various classes of stockholders have been approved by the Supreme Court." Id. at 311.

The plaintiffs further alleged that under the provisions of the act, parties in their position are deprived of property without due process of law in that seventy-five per cent of each class of stockholders are given the power to deprive twenty-five per cent of their contract rights with the railroad corporation. Id. at 311. The court answered as follows: "Congress is the proper branch of the government to declare policy and, having found a danger existing, to design the legislative machinery to avoid or repel the danger. In enacting the ... [Railroad Modification] Act, Congress defined the danger and designed appropriate machinery to obviate it. If contract rights stand in the way of the exercise by Congress of a power within its competence under the Constitution, the contract right must fall... . Legislation of the character represented by Section $20 \mathrm{~b}$ is designed to modify or alter contract rights-not capriciously, but in order that the relationship between the security holder and his fellows, and between the security holders and the corporation, may be stated in terms of present day realities rather than in terms that are so remote from reality as to be misleading. . . . The Commission, having regard for the Congressional policy expressed in the ... Act, found after extensive investigation that the plan was just and reasonable as to all classes of the Railroad's shareholders. It appears to the Court, from the cases cited, that a denial of due process does not arise from the fact that the dissenting stockholders will be deprived of certain contract rights." Id. at 311-12.

${ }^{183}$ Missouri-Kansas-Texas R.R. Securities Modification, 275 I.C.C. 499 (1950).

${ }^{184}$ The bonds were in part held publicly, but the report does not mention the distribution of ownership. 
the accumulation, and this process easily could have been completed in another four years if earnings remained at existing levels. The plan of modification provided for discharging the whole of this liability immediately by giving the junior bondholders, in a face amount equal to the accumulation, new secured debentures which were to mature at the same date as their bonds and bear interest at 1 per cent, contingent on earnings but cumulative to a ceiling of 4 per cent. Junior bondholders objected to the plan, ${ }^{185}$ which the applicant defended, by pointing out, among other grounds, that the accumulation of unpaid interest involved "its officers in continual correspondence and discussion concerning the payment ... of some portion of such outstanding accumulations." 186 The ICC disposed of the application on the basis that the company failed to establish that its situation came within any of the specific categories entitling a carrier to a modification of securities under section $20 \mathrm{~b} .{ }^{187}$ In particular the Commission held that the road could not qualify under the gateway which authorized modification to improve the marketability of securities impaired by long and "continuing" accumulations. 188

More germane to our inquiry, the ICC also found that the plan would not be in the best interests of the junior bondholders. There was testimony that the new 1 per cent debentures would sell at a very substantial discount. "Thus," says the Commission, "it is clear that ... if the ... bondholders should sell their debentures prior to [maturity in] 1967, they would surrender a right to a large amount owing them."189 This would result in "the applicant purchasing their rights to the accumulations at less than the full amount thereof regardless of earnings," even though "prospective earnings would ... cover ... [payment in full] by a large margin in the next 4 years."

Perhaps such a brief discussion of the subject is all that was merited, since the application was being rejected on a more basic count. It nevertheless is disappointing that the report does not refer to other modification proceedings or mention any doctrine for determining when an exchange is in the best interests of bondholders. One looks in vain for full compensation language or talk about

${ }^{185}$ The objectors were institutional investors. 275 I.C.C. at 499 . They asserted that the proposal "is unfair and inequitable and violates the established rule of priority for their claims." Id. at 505 . However they also stated that "they are willing to make some compromise in order to eliminate the interest accumulations. ..." Ibid.

${ }^{186} I d$. at 504 . As to this contention, the ICC said, "we would not be warranted in invoking, for that reason alone, the provisions of section 20b." Id. at 508 .

${ }^{187}$ Id. at 511.

${ }^{188}$ Id. at 508-10. "Furthermore the applicant has failed to show that the issue of secured debentures as proposed is reasonably necessary or appropriate for purpose of liquidating the accumulated unpaid interest on its adjustment-mortgage bonds." Id. at 511.

${ }^{189}$ Id. at 510.

${ }^{190} \mathrm{Id}$. at 511 . 
economic equivalence. Conceivably the Commission thought that recourse to generalizations was unnecessary where a deal concocted for the bondholders would short-change them as much as this scheme.

j) Maryland \& Pennsylvania Railroad (December 20, 1950). ${ }^{191}$-The major components of the debt of the Maryland \& Pennsylvania, a relatively small road, consisted of 4 per cent first mortgage bonds due to mature within a year and a smaller amount of 6 per cent first consolidated mortgage bonds due to mature in 1963, both issues being held largely by the public. ${ }^{192}$ Taking into consideration that the two issues had first liens on different properties and that a portion of one issue was pledged to secure the other, the ICC thought that they were "about equally secured per $\$ 1,000$ of each outstanding." 193 Under the proposed plan, which was prompted by the near maturity of the first mortgage bonds, (1) maturities of both debts would be extended thirty years through the issuance of two new series of bonds of equal rank but different maturities; (2) interest would be made partly contingent, the change affecting one-half of the 4 per cent interest on the first mortgage bonds, and two-thirds of the 6 per cent interest on the consolidated mortgage bonds (with one-half of the two-thirds being of a rank inferior to the other contingent interest payments); and (3) about 19 per cent of the total equity would be given to the bondholders, to be divided between them in proportion to the sizes of the two bond issues. ${ }^{194}$ No opposition to the plan was forthcoming. ${ }^{195}$ Observing that earnings "will probably not be sufficient to pay contingent interest as it matures," the ICC stated that "it would not be in best interest of the bondholders to require them to surrender their rights to interest payments and leave the equity of the stockholders in the property virtualy [sic] untouched as proposed."196 Either the Commission thought that for this purpose 19 per cent of the equity was not a significant portion, or it was ineptly pointing out that the old shareholders would retain control over the road and thus over payment of the contingent interest. In any event the Commission required that contingent interest on the new bonds be fully cumulative, and then approved the plan as so amended. ${ }^{197}$

There is no mystery why the percentage of the equity to be awarded the bondholders here, 19 per cent, is almost identical to that given up by the stockholders in the Lehigh Valley modification. We are enlightened that "to support this phase of its plan" the applicant relied on the Lehigh Valley decision..$^{198}$

191 Maryland \& Penn. R.R. Securities Modification, 275 I.C.C. 695 (1950).

192 Id. at 697. ${ }^{193} \mathrm{Id}$. at 713.

194 The proposal also affected a note held by a bank and an issue of first income bonds due to mature soon, a small fraction of which was held by seven persons and the balance of which was pledged to secure the consolidated-mortgage bonds. $I d$. at 715 . These aspects of the plan are ignored here, but it should be observed that the ICC uses full compensation language only with reference to the note. $I d$. at 712 .

${ }^{195} I d$. at 695 . "The plan ... was formulated by the applicant in conferences with holders or representatives of holders of large amounts of the securities affected . ..." Id. at 708 .

${ }^{196} I d$. at 715 .

${ }^{197} \mathrm{Id}$. at $715,723$.

${ }^{198}$ Id. at 714 . 
Possibly it is also more than a coincidence that the Commission does not discuss the adequacy of the fraction going to the bondholders, merely citing Lehigh Valley to the effect that no definite formula can be followed in all modifications, but that just about everything is to be taken into account. ${ }^{199}$ In a footnote we are informed that the market value of a share was about fifty cents. ${ }^{200}$ At that level each holder of a $\$ 1000$ bond would receive shares worth about $\$ 2$; and both classes of bondholders together would receive shares worth in all about $\$ 2,200$, which comes to about two-tenths of 1 per cent of the principal amount of their bonds. But considering the changes the bondholders were being asked to accept, only a cynic would suggest that these figures could possibly be a clue to why the Commission passed up the opportunity to discuss the adequacy of the 19 per cent.

One other aspect of the report bears on our inquiry. Having decided that part of the interest burden must be made contingent in view of the earnings record, the ICC says there is a question "as to which class of the ... [bonds] should be required to make the sacrifice with respect to interest."201 The two issues, as noted previously, were regarded by the Commission as "about equally secured per $\$ 1,000$ of each outstanding." But under the plan the old 4 per cent first mortgage bondholders get a new 4 per cent bond on which half the interest is unconditional, while the old 6 per cent consolidated mortgage bondholders receive a new 6 per cent bond on which only one-third of the interest is a fixed obligation. The Commission nevertheless specifically finds that such treatment is "just and reasonable." 202 In so concluding it states that consideration had to be given the fact that "while the 6 percent interest rate of the consolidated bonds seems high as compared to the 4 percent rate of the first-mortgage bonds," which mature soon, "the . . . consolidated mortgage represents a contract which does not mature until ... 1963."203

At first sight this might appear to say that the consolidated bonds are entitled to a better new security than the first mortgage bonds because their relatively high old interest rate was due to continue for many years. On closer inspection, however, the message seems to be that in evaluating the consolidated bonds, their distant maturity should constitute a minus rather than a plus factor. So interpreted, it might account for why the consolidated bondholders were to have two-thirds of their interest claim made contingent, whereas the first mortgage bondholders were to lose only one-half their fixed interest claim. But regardless of what position the Commission meant to convey, there is no indication why it thought that a distant maturity should be viewed as weakening or strengthening the bondholders' claims.

The confusion here stems from a source we have commented on earlier. ${ }^{204} \mathrm{~A}$ distant maturity in a bond should be a positive element if the bond carries a

199 Ibid.

${ }^{200}$ Id. n.7.

${ }^{201} I d$. at 713 .
${ }^{202} I d$. at 714.

${ }^{203} \mathrm{Id}$. at 713 .

${ }^{204}$ See text at p. 626 supra. 
relatively high rate of interest; and, similarly, a near maturity should be a positive element if the coupon rate is relatively low. What is needed in each case is a yardstick for determining whether the rate on a particular bond is relatively high or low in the light of the risks entailed. That which comes most readily to mind is the yield currently obtainable in the market on comparable obligations. In the Maryland \& Pennsylvania report the ICC again took no steps to evaluate the interest rates on the two series of bonds in the light of market yields. Nor did it offer any other gauge as a substitute. The result is that both the reader and the Commission are left without any guide for deciding which, if either, got the better deal-the longer term, higher interest rate consolidated bonds or the shorter term, lower interest rate first mortgage bonds.

k) Western Maryland Railway (October 14, 1954). ${ }^{205}$-Almost four years elapsed before the ICC issued another report on a proposed railroad modification. ${ }^{206}$ This was in response to the proposal of the Western Maryland, a relatively large carrier, which was burdened with a substantial arrearage on its 7 per cent fully cumulative, non-redeemable, $\$ 100$ par first preferred shares. The arrearage, which had developed during the twenties and thirties, amounted to $\$ 126$ a share, after being reduced in the past few years by $\$ 7$ a share. In order to eliminate the arrearage altogether through capitalizing it with new preferred shares, the plan also had to deal with the company's smaller issue of 4 per cent non-cumulative second preferred stock. Under the proposal, as amended in minor respects by the Commission, (1) the holder of a first preferred share would receive two shares of a new 5 per cent, cumulative to 15 per cent, $\$ 100$ par first preferred, redeemable at $\$ 105$, plus one-half share of a new 4 per cent non-cumulative $\$ 100$ par second preferred, convertible into one share of common; (2) the holder of a share of the old 4 per cent second preferred would receive one share of the new 4 per cent second preferred, convertible into two shares of common; and (3) the holder of a share of the old common would get one share of the new common. Even if all the new second preferred shares were converted, the old common stockholders would not lose control of the road. ${ }^{207}$

${ }^{205}$ Western Maryland Ry. Securities Modification, 290 I.C.C. 445 (1954).

${ }^{206}$ However, in the interim the ICC had occasion to refer to modifications as a result of a suggested plan for reorganizing the Wisconsin Central Railroad Company which was in reorganization under Section 77 of the Bankruptcy Act. The suggested plan was "based on the hypothesis that the debtor should be reorganized 'not as a bankrupt but as a corporation of proven solvency' on the theory that, if given time, it can pay off its indebtedness." 282 I.C.C. 393,502 (1952). The proponents contended that such a plan, which would give "not only junior creditors but also the stockholders a chance to preserve their investments," would meet "the desires of Congress as indicated by its enactment of section $20 \mathrm{~b}$ of the Interstate Commerce Act." Ibid. The ICC responded that paragraph 13 of the section, which applies where a carrier is in bankruptcy reorganization, "specifies, as a prerequisite to our consideration of a plan for alteration or modification of securities... the entry of an order by the judge of the bankruptcy court permitting application to the Commission for approval of such a plan," and that, "in the absence of such authority, we cannot entertain in a section 77 proceeding a plan which is avowedly and patently designed for use in a section $20 \mathrm{~b}$ proceedings." Ibid.

207290 I.C.C. at 451 (1954). 
It is also important to know that the Baltimore \& Ohio owned 94 plus per cent of the old first preferred, 13 plus per cent of the old second preferred, and almost 30 plus per cent of the old common, all of which was held in a voting trust. ${ }^{208}$ The Baltimore \& Ohio supported the proposal, but there was opposition from other owners of the old first preferred, ${ }^{209}$ who asserted that "it does not afford them the full economic equivalent of their present holdings; and that it is unduly favorable to holders of second-preferred and common stocks." 210 The ICC approved the plan, after making minor amendments, ${ }^{211}$ with one Commissioner dissenting. ${ }^{212}$ In so doing, it overruled the examiner, who had recommended that the application be denied mainly because the situation was outside the scope of section $20 \mathrm{~b}$ since there was no "continuing accumulation of dividends." 213 "We," said the majority, "do not construe the phrase 'continuing accumulations of interest on income bonds and dividends on preferred stocks," " as used in section $20 \mathrm{~b}$, "to embrace only situations where the amount of accumulations are increasing." 214

The report contains a considerable amount of material thought to bear on whether the plan provided the first preferred shareholders with the economic equivalent of their old rights. There is testimony by both sides as to the probable length of time needed under existing conditions for clearing up the arrearage, which of course would depend on earnings available for the purpose. It is somewhat surprising that "none of the applicant's witnesses attempted to forecast its probable annual earnings in ... [future] years," or to present "a forecast of a future normal year."215 However, the plan explicitly was based on estimates that "average annual net income in future years should equal or exceed" a given level, of which a specified amount usually would be available for dividends. ${ }^{216}$ Estimates of the period for paying off the arrearage ran from ten years ${ }^{217}$ (which the ICC apparently thought too short) to forty years ${ }^{218}$ (which the ICC apparently thought too long). Other evidence introduced by the applicant was to the effect that revision of the capital structure would in itself be beneficial. It was said that elimination of the arrearage would turn the company's stocks into normal investment media instead of special situations; the split of the first preferred into a larger number of shares would increase their aggregate market value; and a 5 per cent preferred would ordinarily sell at a

${ }^{203} \mathrm{Id}$. at 446 . The balance of the stock seems to have been held, in part, by the public, but this is not made explicit in the report. Id. at 469-71. One brokerage firm appeared to speak for a substantial number of the shareholders (other than the Baltimore \& Ohio) and played "an important part" in formulating the proposal. Id. at 469. Also, market quotations for both classes of preferred and for the common were presented. Id. at 454.

209 Id. at 445.

${ }^{210} I d$. at $455-56$.

211 Id. at 474.

212 Id. at 475.

213 Id. at 461 .
214 Ibid. See note 143 suprc.

$215 I d$. at 456.

215 Ibid.

217 Id. at 458 .

218 Id. at 457 . 
higher multiplier of its dividend than a 7 per cent preferred with similar characteristics. ${ }^{219}$ No comment on these points was made by the Commission. Evidence was offered by the intervenors as to the dollar value of the fully cumulative feature of the old first preferred, which was not carried over to the new preferred. The Commission brushed this aside with the comment that "we do not deem it desirable or practicable to assign separate values to the various features of the stocks involved."220 Instead, it says, consideration must "be given to all the attributes of the old and the new securities." ${ }^{221}$ As might be expected, this is followed by an enumeration of the merits and demerits of the old securities as contrasted to those of the new package to be received in exchange. There is then summarized much testimony by witnesses for both sides regarding the probable market values of the new securities, along with statements as to the "market value" and "value" of the old first preferred, and the "value" of the arrearage. ${ }^{222}$ Estimates of the "market price" for the package to be substituted for a share of old first preferred ranged from $\$ 175$ to $\$ 235$; while estimates of the "value" of the old first preferred (the current market price being $\$ 180-\$ 185$ ) ranged from a high of $\$ 238$ (which the ICC noted was based on the fallacy that the $\$ 126$ arrearage has a present value of $\$ 126)$ to a low which treated the arrearage as worth $\$ 70$. Immediately after its protracted recitation of testimony and scattered commentary, the ICC abruptly concludes that: "Upon consideration of all the evidence, we are of the opinion, and find, that the new securities to be received by each class of present stockholders will have a value at least equal to the value of the securities and rights which will be surrendered therefore... [and] that stockholders of each class will receive the fair economic equivalent of the rights to be surrendered. . .."223

We have here an almost perfect specimen of the hotchpot method of reaching a conclusion. All things, including values, market values, qualities and quantities, are thrown together and suddenly an answer emerges. Again it is important to emphasize that the answer which is called for-whether something is the economic equivalent of something else-never can be reached by mathematical computations alone; human judgments are inescapable. What is notable about the hotchpot method is that it provides maximum camouflage for these judgments. Thus we cannot tell how long a period the Commission thought would be needed to pay off the $\$ 126$ arrearage on the first preferred, even though there were a wide range of estimates and it had observed that "discounted on the basis of 6 percent compounded annually, the present worth of $\$ 126$ payable in $10 \ldots$ or 20 equal installments is $\$ 92.74 \ldots$ and $\$ 72.26$ respectively." ${ }^{224}$ Occasionally we do learn that the Commission disagrees with certain testimony or propositions. More often, however, conflicting testimony is merely reproduced without comment, so that we are left in doubt whether any or all of it goes into the pot, and what weight is attached to it.

$\begin{array}{lll}{ }^{219} I d . \text { at } 462 . & 221 \text { Ibid. } & 223 \text { Id. at } 467 . \\ { }^{220} I d . \text { at } 463 . & 222 \text { Id. at 464-67. } & 24 \text { Ibid. }\end{array}$


The uncertainty is aggravated by the varying conceptions of value which enter into the report. The Commission states a single general rule, also found in other modification opinions, for determining whether the plan is in the best interests of the preferred shareholders: They must receive the "fair economic equivalent of the rights to be surrendered."225 But despite pages of testimony and discussion bearing on values, we never learn whether economic equivalency is to be in terms of probable near-term market values, probable long-term market values, appraised values having no relation to market values, or some unlikely combination of these. Not knowing this, it becomes doubly difficult to second guess the Commission. By the same token it is all but impossible to post a score for the dissenting Commissioner who said: "Nor am I convinced of the soundness of the finding that ... the applicant's first-preferred stock will receive securities 'at least equal' to the value of those surrendered."

Finally we should look closer at the "at least equal" finding of the majority. It implies that the senior preferred shareholders might be getting more than they give up. If this were in fact the case, how could the plan be in the best interests of the other stockholders? One possible answer is that the reshuffling of the capital structure might result in the market placing a higher value on the company's securities in the aggregate, thereby enabling all classes of shareholders to receive in the modification new paper more than equal the value of their old. ${ }^{227}$ This possibility, however, raises a question which is never acknowledged by the Commission. If the modification does enhance the value of the whole, is the increase to be shared among the affected classes, or is it to be allocated exclusively to the common shareholders on the theory that senior classes are entitled to full compensation and nothing more?

In the end the proposal lost when the district court held that it did not come within the scope of section $20 \mathrm{~b}$. The court construed the statutory phrase "large and continuing" accumulations to mean, not a large accumulation that will continue for a long period, as held by the majority of the Commission, but an accumulation which is presently continuing to grow. ${ }^{228}$

225 Ibid.

${ }^{225}$ Id. at 476. The dissenting Commissioner added: "They [the holders of the first-preferred stock] now have priority as to any earnings distributed. This plan dilutes that priority." Ibid.

${ }^{27}$ On the relationship between capital structure and the aggregate market value of securities, see Graeasr and Dodd, Security ANarysis Ch. 37 (3rd ed. 1951); Guthman, Absolute Priority in Reorganization: Some Defects in a Supreme Court Doctrine, 45 Coluns. L. REv. 739 (1945).

${ }^{29}$ Wood v. United States, 132 F. Supp. 586, 592 (S.D.N.Y. 1955). In this case, the Attorney General confessed error and contended that the plan does not come within the scope of section $20 \mathrm{~b}$. (Id.at 590).) In distinguishing between a large arrearage that will continue for some time and a growing arrearage, the court observes in a footnote that: "This distinction hass been invoked by the Commission itself. In Maine Central . . . a plan was rejected as being outside the scope of 20 (b) where the prospects for reasonably prompt removal of arrearages were good. But in Boston and Maine ... , where arrearages could be expected to last for 74 years, and further accumulations could be expected for 17 years, a modification plan was approved. In the case of Western Maryland, the Commission found that the arrearages might be paid off in 10 to 18 years." Id. at 592 n.8. 
l) Missouri-Kansas-Texas Railroad (stock proposal) (July 15, 1958).229_ Not quite another four years passed before the ICC again dealt with the subject of our inquiry in a railroad modification proceeding. In mid-year 1958 the Commission considered the plan of the Missouri-Kansas-Texas (whose application concerning junior bonds had been denied in 1950) to eliminate the high $\$ 166$ per share arrearage on its 7 per cent cumulative $\$ 100$ par preferred stock. ${ }^{230}$ The arrearage has been accumulating since early in the thirties and there was "no hope that... [the company] could... even pay dividends in sufficient amounts to prevent a further increase therein." 231 Under the proposed plan, which incidentally was designed to achieve a federal income tax advantage by substituting debt securities for equities, each preferred share would receive a package with three components: (1) $\$ 100$ principal amount of $5 \frac{1}{2}$ per cent debentures to mature in seventy-five years, interest contingent on income and to cumulate to a maximum of 10 per cent; (2) a $\$ 100$ non-interest bearing certificate, to be retired out of a contingent sinking fund into which certain percentages of income would be placed after other charges; and (3) a share of common stock, which would give the preferred shareholders about 45 per cent of the common shares after the reshuffling. Some preferred shareholders opposed the proposal..$^{232}$ The ICC approved it after making several amendments. ${ }^{233}$ Interest on the new debentures was to cumulate for three years whether earned or not, for the reason that earnings are likely to fluctuate considerably; no dividends were to be paid on the common until 60 per cent of the certificates had been retired (and there was to be a larger allotment of income to the sinking fund for retiring and certificates); the face amount of the certificates was to be increased from $\$ 100$ to $\$ 110$, because no dividend had been aid to the preferred shares during the immediately preceding year; and the new debentures were specifically to be made subordinate to all other indebtedness of the road at any time outstanding, so as not to adversely affect other unsecured creditors or impair its ability to get credit in the future.

In finding that the plan was in the best interests of the preferred shareholders, the Commission neither restated the "fair economic equivalent" test which

22929 I.C.C. 759 (1958).

${ }^{230}$ This stock was held publicly, but the report makes no mention of ownership, other than to state that $75 \%$ of the total number of shares outstanding is not held by fewer than 25 owners (id. at 777) and to note some market quotations for the shares. Id. at 771 .

${ }^{231} I d$. at 770 .

232 Id. at 759. The objectors contended, among other things, that "the plan is unduly preferential to the present holders of applicant's common stock at the expense of the preferredstock holders." Id. at 765. Some objectors also contended that the plan "is not necessary." Ibid. It was pointed out by objectors that preferred-stockholders "now have a limited tax exemption on account of dividends received which may be materially increased in the future, and, to the extent that it exists, it tends to offset any tax savings to the applicant." Id. at 771. The ICC notes that "the record indicates that three holders of relatively large blocks of common stock took a prominent part in the formulation of applicant's proposal." Id. at 773 .

${ }^{233} \mathrm{Id}$. at 780. 
figures so prominently in its Western Maryland opinion, nor repeated the full compensation language which appeared in several other reports. A possible explanation is that here the Commission concluded that the preferred "are entitled to receive all amounts which applicant's board of directors could declare as dividends in the foreseeable future," and that the principal value of the common (three holders of which "took a prominent part in the formulation of [the] proposal") "lies in its power to exercise control." nomic equivalency or full compensation notions might have been incompatible with leaving 55 per cent of the equity in the hands of the old common shareholders. In this respect the present situation resembles that in Boston $0^{\circ}$ Maine where it was remarked that the common stockholders could not be expected to vote themselves out of the company. ${ }^{235}$ No reference to this similarity is contained in the report.

The process followed in determining that the plan was in the best interests of the preferred shareholders is noteworthy. The Commission made a specific finding that " $\$ 100$ principal amount of debentures would be about the equivalent of each share of preferred stock minus dividend accumulations. ${ }^{236}$ But there is no reported testimony or other evidence which furnishes a foundation for the proposition that a 75 year $5 \frac{1}{2}$ per cent income debenture is equal to a 7 per cent non-redeemable preferred share. Only the naked conclusion is made available. Thereafter the Commission observes that "in a normal year the preferred stockholder would receive a larger share of applicant's earnings as interest on debentures and from retirement of certificates than he would from preferred stock dividends, and his voting rights would not be disturbed." ${ }^{237}$ This statement is misleading. The preferred shareholders are entitled not only to annual dividends but also to payment of their arrearage before dividends can be distributed to the common shareholders. To compare annual dividends on the preferred with a combination of interest on the debentures plus payments to retire the certificates tends to be deceptive unless the arrearage is included. A witness estimated that initially the market value of the proposed package would total about $\$ 77$ as compared with a then prevailing market price of $\$ 57$ for a share of preferred. ${ }^{238}$ But apparently this is not reported to substantiate the conclusion of the Commission, inasmuch as it remarks that "real values of securities are not always measured by their market prices which at most reffect the opinions of those engaged in buying and selling the securities at a particular moment."2339 It might well have added that the market price for the preferred undoubtedly was affected by expectations as to how the preferred would fare in a modification proceeding.

This exhausts the analysis presented in support of the conclusions that the

234 Id. at 773 .

${ }^{235}$ See p. 634 supra.

${ }^{238} 295$ I.C.C. $759,773$.
${ }^{237} I d$. at 776 .

${ }^{238} I d$. at 771 .

239 Ibid. 
plan is in the best interests of the preferred shareholders. ${ }^{240}$ Some major omissions might be noted. Having found that a new $\$ 100$ par $5 \frac{1}{2}$ per cent debenture equals a share of $\$ 100$ par 7 per cent preferred, the Commission does not enquire whether the remainder of the package is equivalent to the (growing) arrearage. No effort is made even to value the arrearage; and one can only wonder why the ICC bothered to find an equality between the debenture and the preferred, absent an arrearage, when it does not treat with the rest of the package. Further, the Commission never mentions explicitly that the preferred stockholders would end up under the plan with 45 per cent of the common. That fact, which would seem to be of crucial importance, can only be derived from the figures presented.

Is there a plausible explanation for the thin and incomplete character of the analysis in this opinion? Possibly there is a clue in the Commission's notation that the principal value of the common "lies in its power to exercise control."241 The ICC seems to have accepted the position that the old common stockholders were entitled to stay in control for, after all, the company could not be forced into a section 77 bankruptcy reorganization merely because of the arrearage. The plan did no more than concede that control by allowing them to retain 55 per cent of the equity after the modification. Everything else was given the preferred shareholders, and in this sense it might be said that the plan was in their best interests.

m) Boston \& Maine Railroad (bond proposal) (February 25, 1960). ${ }^{242}$-The most recent railroad modification report, like the one immediately preceding it, was also a return engagement. Having received approval a decade ago to alter its equity securities, the Boston \& Maine this year sought to modify parts of its bonded indebtedness. Of a total of around $\$ 53,000,000$ first mortgage bonds, the 4 per cent RR series, amounting to about $\$ 49,000,000$, was due to mature July1, 1960 , and the 42 per cent series, secured identically and amounting to about $\$ 900,000$, was due to mature nine months later. Because the carrier was not in a position to retire or refinance these near maturities, it advanced a plan to exchange the old bonds, in like face amount on a pro rata basis, for new 6 per cent first mortgage bonds, 20 per cent of whose principal sum would mature in each of the succeeding four years and the balance in the fifth year. The plan was formulated by the applicant after discussions with several large holders of the RR series (which was listed on the stock exchange), and "expressions of assent" had been received "from insurance company members of the Institutional Bondholders owning, in the aggregate, ... more than 40 per cent of the total

${ }^{240}$ On the subject of the plan being in the best interests of the common stockholders, the ICC says "the voting rights of the common-stockholder would not be disturbed, but his prospects for dividends would be enhanced somewhat." Id. at 776 .

211 Id. at 773.

242 Boston \& Maine R.R. Bonds Modification, I.C.C. Finance Docket No. 20836 (February $25,1960)$. 
outstanding principal amount of these bonds." ${ }^{243}$ Opposition was forthcoming mainly ${ }^{244}$ from a mutual fund trustee which owned about 70 per cent of the JJ series (which was also listed on the stock exchange); no assurances of assent had been obtained from any holders of this series since "only in a rather oblique manner was any effort made by the applicant to engage in any discussion with these bondholders." 245 The mutual fund trustee contended that the two series of bonds should be classed separately ${ }^{246}$ and, in the alternative, that the plan is not fair to the holders of the JJ series if the two series are held to be a single class. In a report by the full Commission, the plan was approved by the ICC without amendment. ${ }^{247}$

The fairness of the proposal was challenged by the mutual fund trustee "primarily on the fact that the proposed interest rate of 6 per cent on the new... series will represent a 50 percent increase over the present 4 percent rate borne by the RR series but less than that over the present $4 \frac{3}{4}$ percent rate borne by the JJ series, and that preservation of the same differential with respect to the latter, would require an interest rate of $7 \frac{1}{8}$ per cent, instead of the proposed 6 per cent for the new bonds. ..."248 On this basis of comparison the trustee contended that "the plan proposes to pay the holders of the RR bonds more for forbearance until 1965 than it proposes to pay to holders of the JJ bonds ...."249 The ICC flatly rejected this argument, saying that it "disregards the impending maturity ... within a nine-month period as the controlling event which has brought about the proposed modification plan." series would give up continuance of its coupon rate after maturity because neither has a legal right to have the existing coupon rate continued in such a refunding."251 Moreover, according to the "uncontradicted evidence of expert financial witnesses," in a case of this kind "it is both customary and fair to provide an interest rate on the extended bonds of all series of a class, irrespective of their pre-existing contract rates, consistent with the current rates in the market; in other words, the going rate of interest considered to be compatible with the credit standing of the railroad should govern, and the existence of a

${ }^{243}$ Id. at 13 .

${ }^{244}$ Opposition was also voiced by an individual who intervened in his own behalf as a stockholder; the ICC notes that he also owned "a $\$ 100$ series RR bond purchased after notice of hearing in this matter was issued." Id. at 14.

245 Ibid.

${ }^{246}$ The ICC found that "there are not such substantial differences in priorities, claims, or interests as between the series RR bonds and the series JJ bonds as to justify their being separately classified." Id. at 37 . It noted that "if the JJ bonds are separately classified, then the plan could be defeated by the vote of just over 25 per cent of that single class, or equivalent to slightly less than one-half of one precent of the total principal amount of both series of bonds." Id. at 36.

${ }^{217} \mathrm{Id}$. at 58.

${ }^{248} I d$. at $40-41$.

${ }^{250} \mathrm{Id}$. at 43 .

249 Ibid.

251 Id. at 44 . 
higher rate of interest prior to maturity, as between two series whose terms are to be extended, does not justify a differential rate after extension."252

To back up this answer, the Commission goes on to argue that "if any differential in compensation is to be accorded the holders of either series of bonds, the equities for better treatment would appear to lie with the $R R$ bondholders. ..."253 Two considerations are marshalled for support. The RR bonds mature nine months earlier, and 'this 'right' of prior payment, if exercised, would permit the holders of $R R$ bonds, through reinvestment of their principal, to earn considerably more than 6 or even $7 \frac{1}{8}$ percent (probably as much as $8 \frac{3}{4}$ percent), ${ }^{, 254}$ and in any event more than the $4 \frac{3}{4}$ per cent rate payable on the JJ bonds, during that period. Further, while the JJ bonds "are being extended for only $4 \frac{1}{3}$ years, they will receive the benefit of the higher interest rate for 5 years," so that for the first nine months of the period they "will be getting more than their contract rate of interest."255 The ICC recognizes that "to justify the additional compensation involved in this increase, it would be necessary to disregard the right of the $R R$ bonds to be paid nine months prior to the JJ bonds." ${ }^{256}$ But apparently it is willing to forget this right, inasmuch as it finds that identical exchanges for the two series is "fair" sacrifice asked of the holders of the RR bonds is the greater of the two."

Nothing is to be gained by dwelling on the point that the Commission seems to demonstrate successfully that the plan either is unfair to the RR bonds in not giving them enough or is unfair to the stockholders in giving the JJ bonds too much. No doubt this result can be charged to the zeal with which the ICC tries to dislodge a tenacious objector and defend the proponents and endorsers of the plan. Another aspect of the analysis, however, seems more deserving of comment. In reviewing several prior modification proceedings, attention has been directed to the measure of what bondholders are entitled to receive where an extension is being sought for bonds which have already matured or will do so soon. ${ }^{259}$ This should be the vital question here, although it is not framed directly as the key issue by the Commission, presumably because of the position taken by the cooperating institutional bondholders. For our purposes, it is critical to ask why it is proper that the old maturing bonds be exchanged for new 6 per cent bonds rather than new 4 per cent or 8 per cent bonds, or some other securities package.

The Commission's apparent answer can be found by putting together several elements in the report. In a passage dealing with the necessity for a plan, it is

${ }^{252}$ Ibid.

${ }^{253} I d$. at 45 .

${ }^{256}$ Id. at 45.

251 Ibid.

${ }^{257} I d$. at 46.

$255 I d$. at 46.

258 Ibid.

${ }^{259}$ See discussion of Atlantic \& Danville, Bangor \& Aroostook, Maryland \& Pennsylvania, sutpra pp. 623, 631, 643. 
noted: "In the opinion of the applicant, its counsel, and witnesses, the proposed modification, or a substantially similar one, is the only alternative to default on its obligations on these bonds, with consequent resort to reorganization under section 77 of the Bankruptcy Act or some other type of relief involving receivership or bankruptcy." ${ }^{260}$ Later the Commission characterizes the proposal as an "extension of the terms of the two series at ... a an interest rate more nearly conforming to rates currently prevailing on comparable securities."261 This apparently was not a reference to market yields, however, since "there was expert opinion evidence on behalf of the applicant that the package of new ... bonds... would have an estimated market value of upwards of the middle 70's ...."262 The explanation of why an exchange for a new security of this quality is acceptable to the Commission seems to lie in its observation that the "treatment ... is predicated on the theory of a refunding of both series substantially at maturity at current interest rates limited only by the applicant's ability to pay." ${ }^{263}$

But what does "ability to pay" mean in this context, and why is such a notion relevant in determining whether an exchange of securities in a modification is acceptable? These questions are not pursued by the Commission, and once again we are thrown upon conjecturing. Perhaps the Commission meant that a higher fixed interest charge would overburden the company; but then any additional interest could have been made contingent on earnings or some other factor. Even if this were regarded as not feasible, it seems odd that the rights of the bondholders should therefore be placed under a ceiling. If their claims entitle them to more, a fraction of the common stock could be given to them without endangering the company's ability to pay. All things considered, ability to pay seems to be without utility in this area unless it imparts the thought that the bondholders would not be able to obtain more favorable treatment in a bankruptcy reorganization. There is no reason to think the Commission was alluding to that alternative as defining the ceiling here.

One item conceivably might help explain why the ICC was satisfied with the proposed exchange. In recording the evidence that the new bonds "would have an estimated market value of upwards of the middle 70's," the Commission remarks that this "would be higher than the market value of the two existing series both currently and at any time during the past year."264 The significance of this point is perhaps indicated by the fact that immediately afterward the Commission rejects the amendment proposed by the mutual fund trustee, and finds that the plan is "fair and equitable and will be in the best interest of bondholders. ..."265 Perhaps the item also helps to account for why not a word is

${ }^{260}$ I.C.C. Finance Docket No. 20836 at 17.

${ }^{201} \mathrm{Id}$. at 43.

${ }^{203}$ Id. at 45.

263 Id. at 46.

261 Id. at 46.

${ }^{265}$ Ibid. The ICC also dealt with the contention of the intervening common shareholder that the plan is not in the best interests of the stockholders in part because "the proposed 
said about full compensation or equitable equivalence, and why, in discussing the acceptability of the proposed exchange, not a single reference is made to any of the earlier modification opinions. ${ }^{266}$

\section{III}

This completes a review of reports under the railroad modification law to date. What conclusions are to be drawn?

Our inquiry was directed to a single question: To what extent has the ICC developed principles for determining what constitutes an acceptable exchange of rights for stockholders or creditors in a modification of railroad securities? The answer which emerges is that virtually no such development is evident despite the insistence of the Commission, in Lehigh Valley, that the statute "lays down in unequivocal language standards for our guidance."267 On a pure mathematical count, the general theme most iterated by the Commission is that a participating security holder is entitled to full compensation for rights surrendered, or to receive the equitable equivalent of his old holdings. ${ }^{268}$ Not even this lofty generalization is stated in all the opinions, ${ }^{269}$ and in some instances it is adulterated with thoughts of relative sacrifice or other unrelated or inconsistent ideas. ${ }^{270}$ Where the theme is allowed to predominate or stand alone, it does not acquire content in the form of subordinate doctrines. From the reports we can harvest examples of situations in which full compensation was (or was not) found to be present; but almost never are we put in a position to state the standard which was employed in measuring the claims surrendered or testing the adequacy of the compensation.

Moreover, it is difficult to ascertain from the opinions whether the Commission subscribes to the view that the best interests criterion is satisfied on a showing that each affected class is better off after the plan than under existing conditions. There are indications in some of the opinions that "how the gains

serial maturities and sinking fund and interest requirements of the plan are burdens which the applicant will not be able to meet." Id. at 49. After noting that this contention is predicated on the intervenor's "own unsupported allegation, contrary to testimony of record," the Commission concluded: "Obviously approval of a plan for the extension of the imminent maturities will be in the best interest of applicant's stockholders." Id. at 50.

${ }^{266}$ In handling the question whether the JJ and RR bonds constitute a single class, the ICC made numerous references to earlier proceedings in which such an issue was raised. Id. at 33-34.

${ }^{267} 271$ I.C.C. 553,589 (1949).

288 "Full compensation" or "equitable equivalence" language appears in the following reports: Lehigh Valley, Central of New Jersey, Maine Central, Boston \& Maine (stock proposal), Maryland \& Pennsylvania (but only with reference to a relatively minor aspect of the plan), and Western Maryland. The AtJantic \& Danville report speaks of "adequate compensation."

${ }_{269}$ "Full compensation" or "equitable equivalence" language does not appear in the following reports: Macon, Dublin \& Savannah; Montana, Wyoming \& Southern; Bangor \& Aroostook; Missouri-Kansas-Texas (both proposals); Boston \& Maine (bond proposal).

${ }^{270}$ The relative sacrifice thought is found in Lehigh Valley and Central of New Jersey (and possibly in Maine (entral). 
are divided is irrelevant," and that the criterion is fulfilled "even when objectors use their obstructive power to force better terms for their class," provided that "the concessions they win from other classes still leave gains to the classes that concede." ${ }^{271}$ But other passages in the opinions indicate that the Commission is very much concerned with the relative treatment of the affected classes, as though the best interests test "required that each of a hierarchy of classes be given all it was entitled to in relation to the others."272

It has been suggested that some of the opinions, at least the earlier ones, can be harmonized by noting that the Commission's approach differs between cases involving comprehensive readjustments and those involving refunding of an arrearage on an issue of preferred stock. "In the comprehensive readjustment cases the maintenance of relative value had been paramount.... [Where] each class of securities will be altered, that is, make sacrifices... merely maintaining relative values may well insure equality of sacrifice."273 But where only one class of securities is affected, at least directly, the "appropriate distribution of burdens will by no means follow automatically from retention of relative worth. For this reason, apparently, the ICC in the Maine Central [arrearage refunding] proceeding apparently broadened 'just and reasonable' to encompass reasonable allocation of sacrifices." ${ }^{274}$ Whether the distinction this suggests could be defended on the merits, which seems highly unlikely, ${ }^{275}$ it is hard to find it reflected in later opinions.

Several times in the reports the Commission gives notice that not all situations call for application of an identical standard, and that differing conditions might require a diversity of rules. ${ }^{276}$ In the end, however, no basis for classifying these conditions is enunciated and the operative factors remain untagged. Despite patience in examining the reports, little continuity can be detected. Citations to earlier proceedings are few in number and sometimes are completely absent. Inconsistencies from one report to another go unnoticed and seemingly relevant similarities are left unremarked. On the whole one gains the im-

271 Masson, NEw SHARES FOR OtD 173 (1958).

$272 I d$. at 371.

${ }^{273}$ Hand and Cummings, Funding Arrearages Under Section $20 \mathrm{~b}$ of the Intersiate Commerce Act, 65 Harv. L. Rev. 398, 414 (1952).

274 Ibid.

276 "Despite the emotional satisfaction to be derived from such [a relative sacrifice] approach, its rationale is not entirely beyond argument. If each class of securities retains the same relative value it had previously, a readjustment might be thought not unfair despite the exclusion of one class from participation in sacrifices. Moreover, it is unclear as to what criterion is to be applied in measuring relative sacrifices if, by hypothesis, estimated postreadjustment value is not decisive. On the other hand, the concept of equality of sacrifices becomes far more attractive when viewed from the standpoint of nonassenting holders of an affected class of securities. To such holders it may seem manifestly unfair involuntarily to exact sacrifices from them while leaving another class of security holders unaffected." Ibid.

${ }^{276}$ See Lehigh Valley and Maryland \& Pennsylvania, supra pp. 617, 643. 
pression that, instead of attempting to provide general rules as guides, the Commission has deliberately proceeded to deal with each proposal in as much isolation as possible. ${ }^{277}$

A recent commentary on the opinions of the independent regulating agencies is distressingly fitting here:

The decisions of the independent regulatory agencies, at least in important cases, are always accompanied by opinions explaining the reasons why the agency acted as it did. But these opinions are very different from court decisions or other familiar important government documents. In the first place, agency opinions contain almost no clear statements of general principle. They are almost always enormously long and filled with facts and statistics, but the reader usually looks in vain for a statement of the basic principles on which the case was decided and on which similar cases presumably will be decided in the future. That is why almost no one reads them except the losing litigants who are seeking grounds for appeal and the judges of the appellate court who must decide these appeals. Since they never seem to come to grips with the real problems and policy issues involved in federal regulatory activities, they are of little interest to anyone else.

Because the [opinions] shy away from broad general principles ... the industry, their attorneys, and the public generally, have no real idea what to expect in the future. It sometimes seems . . . that every case argued before an administrative agency starts from the date of passage of the original regulatory act and argues every issue along the way all over again. ${ }^{278}$

It is worth speculating whether some of the uneveness and inconsistencies in the modification reports might be attributable to several factors which are mentioned but generally are not emphasized in them. In a number of the least satisfactory reports the plan was approved but no opposition had been presented; ${ }^{279}$ in the two proceedings where the plan was not approved, a contest figured prominently; ${ }^{280}$ in a case where the Commission required amendment of the plan despite the absence of opposition, the opinion specifically notes that the

${ }^{277}$ This impression becomes firmer if one compares the railroad modification reports with the corporate reorganization reports of the SEC. The SEC at least seems to have made a major effort to develop doctrines which are to be carried over from one case to another.

The impression is shared by another commentator: "One thing that clearly emerges from an examination of the ICC opinions in all the 20(b) cases is that in totality they do not contain a formula setting forth the priority applicable in such proceedings. It is obvious that the ICC is feeling its way and meeting individual problems as they arise, and the absence of any well established criteria is well illustrated by the frequency with which the views of the ICC have deviated from the views of those who have prepared and proposed plans. . . . [O]f the 14 Section 20(b) proceedings that have been initiated [by 1953], only 7 have resulted in consummated plans and of those 7, only 2 were carried out without substantial amendment by the ICC for reasons pertaining to priority." Billyou, Railroad Reorganization under Section 20(b) of the Interstate Commerce Act, 39 VA. L. REv. 459, 481 (1953).

${ }^{278}$ Hector, Government by Anonymity: Who Writes our Regulatory Opinions?, 45 A.B.A.J. 1260,1264 (1959).

${ }^{279}$ Montana, Wyoming \& Southern; Bangor \& Aroostook; Maryland \& Pennsylvania, supra pp. 627, 631, 642 .

${ }^{280}$ Maine Central and Missouri-Kansas-Texas (bond proposal.), supra pp. 628, 640. 
securities were "held largely by the public",281 and in a number of instances the report states that the proposal was cleared with important security owners. ${ }^{282}$ This combination might suggest that the Commission views its role as varying with both the circumstances of security ownership and the reactions of investors to a modification proposal. Substantial portions of many issues of railroad securities are held by institutional and other large scale investors who are fairly well organized and able to protect their own interests. It is possible that the Commission believes that, where these circumstances exist and no opposition to a plan is forthcoming, its duty is only to review the proposal for flagrant arbitrariness or unsound provisions in proposed new securities. Where opposition is present, its duty is to act as an arbiter in settling or compromising differences. And where securities are widely held by the public and protection from institutional investors is lacking, its duty, although specific opposition to a proposal has not been voiced, is to protect the holders against any inroads on their investment position.

To the extent that it explains disparities among the reports, this thesis is kind to the Commission. But it has an ungenerous side. If the Commission was indeed pursuing such a program, much of what appears in the reports is playacting and many of the difficult passages become indefensible nonsense. These thoughts aside, however, it seems highly unlikely that the Commission was systematically operating on such unexpressed principles. Articulation of them could have been easily arranged and would have made the Commission's task considerably more comfortable on several occasions. Further, even if the Commission was reluctant to spell out and publicize the suggested principles, the various facts which would dictate their application could readily have been developed and highlighted in the opinions. Not only do the opinions frequently underplay these facts, they are devoid of cross references and comparisons of the type which might intimate that the principles were at work. Moreover, while the suggested principles might explain many of the puzzling gaps and incongruities in the reports, numerous others are left unaccounted for by the thesis. ${ }^{23}$ At least in several of the opinions the principles appear not to have

281 Maryland \& Pennsylvania, supra p. 642. But note that this is one of the cases in which it is reported that the plan was formulated in conference with representatives of owners of a large amount of securities.

${ }^{282}$ See, e.g., Missouri-Kansas-Texas (stock proposal), supra p. 648.

${ }^{283}$ The proceedings line up as follows regarding the factors of opposition and amendment: Opposition present: Macon,Dublin \& Savannah; Lehigh Valley; Central of New Jersey (but on the part of stockholders and not of bondholders); Maine Central; Boston \& Maine (both proposals) Missouri-Kansas-Texas (both proposals); Western Maryland.

Opposition absent: Atlantic \& Danville; Montana, Wyoming \& Southern; Bangor \& Aroostook; Maryland \& Pennsylvania.

Approved by ICC without relevant amendment: Macon, Dublin \& Savannah; Central of New Jersey; Bangor \& Aroostook; Boston \& Maine (bond proposal).

Approved by ICC with relevant amendment: Lehigh Valley; Atlantic \& Danville; Montana, Wyoming \& Southern; Boston \& Maine (stock proposal) Maryland \& Pennsylvania; Western Maryland; Missouri-Kansas-Texas (stock proposal).

Not Approved by ICC: Maine Central; Missouri-Kansas-Texas (bond proposal). 
been invoked at all. ${ }^{284}$ And there is always the point that acceptance of the principles would run counter to the statutory scheme. The legislation, as mentioned earlier, contemplates that minorities are entitled to protection from the Commission as well as from the self-interests of the required statutory majorities. A judgment of such a majority-even one composed of sophisticated institutional investors-is not to be the ultimate measure of an individual security holder's protection.

Despite these considerations, it is nevertheless a good guess that in modification proceedings the Commission to a degree has been influenced by the character of the security owners and the extent of opposition to a plan. ${ }^{285}$ Even the most objective and independent of administrative agencies can be expected to bend with the realities. Surely the Commission has been aware that the proponents of a plan must always keep in mind the need for obtaining the requisite consents; as one commentator has remarked: "The concept of fairness must embrace the necessity of getting acceptance, for otherwise the opportunity of the statute is missed." ${ }^{286}$ But it is regrettable that the Commission neither stressed the facts relevant to this position nor wrote its opinions to fit them.

It remains to be questioned, finally, whether the failure to implement the section 20b statutory standard should be charged to the ICC or the legislature. Is it asking too much of a regulatory commission to work out principles for determining when the modification of securities, in companies which may or may not be faced with a reorganization in bankruptcy, is in the best interests of various classes of security holders?287 This is a question which goes beyond the ICC and the railroad modification act, for there have been suggestions that a comparable procedure for altering securities be made available generally to corporations engaged in interstate activities. ${ }^{288}$ The answer, it is

284 See, e.g., Macon, Dublin \& Savannal, and the discussion of that report in the text at p. 610 supra.

${ }^{285}$ An illustration of such a reaction coming to the surface is found in the proceeding to reorganize the Wisconsin Central Railway under Section 77 of the Bankruptcy Act. See note 206 supra. "Nor, does the use of script in the Ceniral R. Co. of New Jersey case . . , , as urged by these proponents, establish a precedent for its use in the instant proceeding. In the lastmentioned case, there was no opposition to such treatment in a securities modification proceeding under section 20(b) of the Interstate Commerce Act. Here, there is opposition, in a bankruptcy proceeding." 282 I.C.C. 393,504 (1952).

286 Masson, New Shares for Otd 376 (1958).

287 This is not to argue that the statute requires the ICC to choose between competing priority theories. See Billyou, Railroad Reorganization under Section 20(b) of the Interstate Commerce Acl, 39 VA. L. REv. 459 (1953).

288 "Whatever the justification for its initial limitation, there is no reason of permanent policy why Sectin 20 (b) should not eventually be amended to apply to other types of carriers regulated by the Interstate Commerce Act, nor why the principles contained in Section 20(b), and its mechanics, appropriately modified, should not likewise be made available to all sorts of corporations." Hand and Cummings, The Railroad Modification Law, 48 Coluns. L. REv. 689, 711 (1948). It has also been urged that $\$ 20 \mathrm{~b}$ be broadened so that it could be utilized by rail- 
submitted, is not overwhelmingly clear-cut. In reviewing the reports an attempt has been made to indicate why the statutory scheme has presented a tough challenge to the ICC. The measure of rights and compensation presumably could not be anchored squarely on liquidation values or priorities, since modification was not intended as an alternative to liquidation as a means of enforcing rights. Nor could it comfortably be based exclusively on investment values of the securities, for doing so would tend to deprive senior security holders of the value of default rights for which they contracted. Once these two conceptions are left aside, it is not easy to construct a measure of rights and compensation which both has general applicability and is rooted in a previously developed principle for assigning or comparing values. At best one can invent various formulations which are vague but perhaps not too far off target. Thus the Commission might have tried to build principally on two notions. For a company threatened with imminent reorganization in bankruptcy, it might have urged that members of a senior class are to fare at least as well in a modification as in a reorganization; and perhaps somewhat better to make it worth their while. For a company not faced with reorganization in bankruptcy, it might have urged that members of a senior class are entitled to receive a package whose investment value is likely to equal or slightly exceed what probably would have been the investment value of their existing securities if no modification proceeding were in the picture; and for this purpose investment value should be determined in the context of anticipated near-term market conditions. In some situations a combination of these two ideas might even be appropriate. ${ }^{289}$

Admittedly these suggested guides are sketchy and are easier stated than applied. No doubt there are alternatives which might serve as well. The overriding point, however, is that even if none of the plausible routes to implementation is entirely satisfactory, the Commission could have tried to operate on the assumption that the furtherance of imperfect rules is better than chaos. Through the very process of taking and defending a definite position, the ICC probably could have sired the emergence of a more adequate set of rules.

roads in a wider range of situations, particularly those involving major changes of capital structures. Hand, The Railroad Modification Law-Its Use in Comprehensive Changes of Capilal Structures, 14 Bus. Law. 470 (1959).

${ }^{289}$ The suggestion in the text might be compared with the following observations: "The specific application of the 'best interests' test in arrearage funding will of course differ greatly from its employment in a plan of comprehensive financial adjustment." Hand and Cummings, Funding Arrearages under Section 206 of the Interstate Commerce Act, 65 HARv. L. Rev. 398, $402 \mathrm{n} .13$. In an arrearage refunding the test is "whether the members of [the affected] class would be better off if the proposed modification is effectuated than they would be if the existing situation remained unchanged." $I d$. at 402 . In a comprehensive financial readjustment "the objective in the usual case will be avoidance of bankruptcy reorganization or the threat thereof. In such a case the ICC therefore must consider to what extent bankruptcy is imminent, and whether the proposal will provide a solution. Finally, the Commission must ascertain if affected security holders will be better off as a result of the proposed readjustment than under a full dress reorganization." Ibid. 
But in the end it must be conceded that there is a distinct possibility that the statutory idea will not sustain a superstructure of orderly elaboration. Perhaps the best interests of each class of security holders in a securities modification is an undefinable conception and therefore can only call for an exercise of informed but very flexible discretion on the part of an administrative agency. ${ }^{290}$ In that event the ICC might have discharged its function better by acting more like a jury. At least it could have avoided giving the impression that it was developing doctrine of general validity while in fact it was making assertions not worthy of an experienced governmental agency. ${ }^{291}$

280 "There is evidence that the Commission regarded expressions like 'just and reasonable' and 'public interest' as descriptive of judgments reached for good reason, rather than as specific techniques of measurement." MASSON, NEw SHARES FOR OLD 179-80 (1958).

${ }^{291}$ Of course the ICC opinions reflect ideas which are put forward by proponents and opponents of plans. This fact, however, should not serve to excuse the ICC of the responsibility for producing opinions which are not consistent or not well reasoned. 